\title{
Cottonseed: a sustainable contributor to global protein requirements
}

Article

Accepted Version

Creative Commons: Attribution-Noncommercial-No Derivative Works 4.0

Kumar, M., Tomar, M., Punia, S., Grasso, S., Arrutia, F., Choudhary, J., Singh, S., Verma, P., Mahapatra, A., Patil, S., Dhumal, S., Potkule, J. ORCID: https://orcid.org/0000-00028126-7027, Saxena, S. and Amarowicz, R. (2021) Cottonseed: a sustainable contributor to global protein requirements. Trends in Food Science \& Technology, 111. pp. 100-113. ISSN 0924-2244 doi: https://doi.org/10.1016/j.tifs.2021.02.058 Available at https://centaur.reading.ac.uk/96843/

It is advisable to refer to the publisher's version if you intend to cite from the work. See Guidance on citing.

To link to this article DOI: http://dx.doi.org/10.1016/j.tifs.2021.02.058

Publisher: Elsevier

All outputs in CentAUR are protected by Intellectual Property Rights law, including copyright law. Copyright and IPR is retained by the creators or other copyright holders. Terms and conditions for use of this material are defined in the End User Agreement. 


\section{CentAUR}

Central Archive at the University of Reading

Reading's research outputs online 


\section{Highlights}

- Physical, chemical, and biological methods for improving utilization of cottonseed as protein source.

- Solvent extraction remains the method of choice.

- Functional properties and amino acid profile for evaluation of quality of cottonseed protein are well discussed.

- Application of cottonseed protein as direct and indirect source of supplement in human nutrition.

- Food safety and regulatory issues for application of cottonseed protein/flour in foods is outlined in the review. 


\section{Structured Abstract}

Background: Cottonseed is a sustainable source of plant protein, producing $~ 10$ million metric tons of protein globally. This protein has the potential to fulfil the annual protein requirement of more than half a billion people globally. Its functional properties have established the potential of cottonseed protein (CSP) as a candidate for alleviating malnutrition in the Asian and African continents. Regardless of these quality attributes, the inherent association of gossypol with CSP makes it unsuitable for direct human consumption due to its toxicity.

Scope and Approach: The present review elaborates on physical, chemical and biological methods for enhancing the quality and suitability of CSP for human nutrition by reducing the gossypol content to permissible limits (450 ppm) per the U.S. Food and Drug Administration and World Health Organization. Amino acid profiling, functional property (water holding capacity, oil holding capacity, foaming properties, emulsification characteristics, and protein solubility), in vitro protein digestibility and molecular weight analyses are the parameters considered important for the application of CSP in foods. This review also highlights the diverse applications of CSP directly in human nutrition or indirectly as animal protein.

Key Findings and Conclusions: Degossypolyzation is mainly performed by solvent extraction, although gamma irradiation and the use of microorganisms are gaining momentum. CSP is a good candidate for use in food and feed formulations, with a balanced amino acid composition and functional properties comparable to those of soy protein. Integration of both chemical and biological methods might prove to be more efficient for degossypolization and improving the utilization of CSP for human nutrition. 
1 Cottonseed: a sustainable contributor to global protein requirements

2 Manoj Kumar ${ }^{\mathrm{a}}$, Maharishi Tomar ${ }^{\mathrm{b}}$, Sneh Punia $^{\mathrm{c}}$, Simona Grasso ${ }^{\mathrm{d}}$, Fátima

3 Arrutia $^{\mathrm{e}}$, Jairam Choudhary ${ }^{\mathrm{f}}$, Surinder Singh $^{\mathrm{g}}$, Pooja Verma ${ }^{\mathrm{h}}$, Archana Mahapatra ${ }^{\mathrm{i}}$, Sharmila

4 Patil $^{\mathrm{j}}$, Radha $^{\mathrm{k}}$, Sangram Dhumal ${ }^{1}$, Jayashree Potkule ${ }^{\mathrm{a}}$, Sujata Saxena ${ }^{\mathrm{a}}$, Ryszard Amarowicz ${ }^{\mathrm{m}}$

$5 \quad{ }^{\mathrm{a}}$ Chemical and Biochemical Processing Division, ICAR - Central Institute for Research on

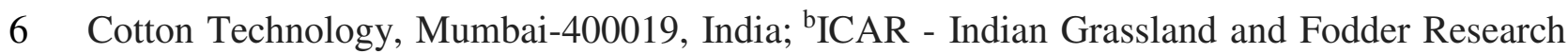

7 Institute, Jhansi, India; ${ }^{c}$ Department of Food Science and Technology, Chaudhary Devi Lal

8 University, Sirsa, India; ${ }^{\mathrm{d}}$ School of Agriculture, Policy and Development, University of

9 Reading, Reading, UK; ${ }^{\mathrm{e}}$ Laboratory of Bioengineering, Earth and Life Institute-Applied

10 Microbiology, Université catholique de Louvain, Croix du Sud, 2 - L7.05.19, B-1348

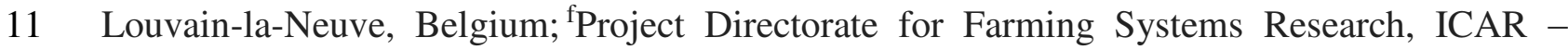

12 Indian Institute of Farming Systems Research, Meerut-250110, ${ }^{g}$ Dr. S.S. Bhatnagar

13 University Institute of Chemical Engineering and Technology, Panjab University,

14 Chandigarh-160014 India; ${ }^{\mathrm{h}}$ ICAR-Central Institute for Cotton Research, Nagpur, India;

15 iTransfer of Technology Division, ICAR - Central Institute for Research on Cotton

16 Technology, Matunga, Mumbai-400019, ${ }^{\mathrm{j}}$ Quality Evaluation and Improvement Division,

17 ICAR - Central Institute for Research on Cotton Technology, Matunga, Mumbai-400019;

$18{ }^{\mathrm{k}}$ Shoolini University of Biotechnology and Management Sciences, Solan-173229, Himachal

19 Pradesh, India; ${ }^{1}$ College of Agriculture, Kolhapur-416004, Maharashtra, India; ${ }^{\mathrm{m}}$ Institute of

20 Animal Reproduction and Food Research, Polish Academy of Sciences, Poland

21 Corresponding author:

22 Manoj Kumar*, Email: manojkumarpuniya114@gmail.com; manoj.kumar13@icar.gov.in 


\section{Structured Abstract}

Background: Cottonseed is a sustainable source of plant protein, producing $~ 10$ million metric tons of protein globally. This protein has the potential to fulfil the annual protein requirement of more than half a billion people globally. Its functional properties have established the potential of cottonseed protein (CSP) as a candidate for alleviating malnutrition in the Asian and African continents. Regardless of these quality attributes, the inherent association of gossypol with CSP makes it unsuitable for direct human consumption due to its toxicity.

Scope and Approach: The present review elaborates on physical, chemical and biological methods for enhancing the quality and suitability of CSP for human nutrition by reducing the gossypol content to permissible limits (450 ppm) per the U.S. Food and Drug Administration and World Health Organization. Amino acid profiling, functional property (water holding capacity, oil holding capacity, foaming properties, emulsification characteristics, and protein solubility), in vitro protein digestibility and molecular weight analyses are the parameters considered important for the application of CSP in foods. This review also highlights the diverse applications of CSP directly in human nutrition or indirectly as animal protein.

Key Findings and Conclusions: Degossypolyzation is mainly performed by solvent extraction, although gamma irradiation and the use of microorganisms are gaining momentum. CSP is a good candidate for use in food and feed formulations, with a balanced amino acid composition and functional properties comparable to those of soy protein. Integration of both chemical and biological methods might prove to be more efficient for degossypolization and improving the utilization of CSP for human nutrition.

Keywords: Cottonseeds; malnutrition; application; plant protein; food safety and regulation; protein isolate 


\section{Introduction}

\subsection{Problem of malnutrition in the African and Asian continents}

Malnutrition is an ever-increasing pandemic throughout Africa and Asia. India accounts for $43 \%$ of malnourished children under the age of five years, accounting for 61 deaths per thousand births. Bangladesh (41\%) is closest-ranked to India, followed by Afghanistan (33\%), Pakistan (31\%), Nepal (29\%), Myanmar (23\%), Sri Lanka (22\%), Thailand (7\%), and China (3\%) (Black and Sesikiran, web source: https://www.nestle.com/sites/default/files/assetlibrary/documents/creating\%20shared\%20value/expert-opinions.pdf accessed on 25/12/2020)

(Fig. 1). Similarly, African countries also show a similar problem of malnutrition in children under the age of 5 years. Malnourished children in most other developing and underdeveloped nations range from high (30-39\%) to very high (>40\%) (United Nations Children's Fund (UNICEF), World Health Organization, International Bank for Reconstruction and Development/The World Bank, 2020). This problem does not end in childhood, as it also persists in the elderly populations of these countries. There is an urgent need to address the dire problem of malnutrition in the Asian and African continents. Consequently, the UN Sustainable Development Summit in 2015 in New York adopted the 2030 agenda for sustainable development, which consists of 17 sustainable development goals (SDGs), out of which 2 SDGs, i.e., goal 2 'Zero hunger' and goal 3 'Good health and well-being', are directly related to alleviating malnutrition. The current review addresses the possible contribution of CSP to accomplishing these goals and alleviating malnutrition.

Fig. 1.

\subsection{Cottonseed as a sustainable protein source}


The global cottonseed production in $2019 / 2020$ is estimated to be $\sim 44.84$ metric million tons (MMT) (Statista, 2020 accessed on 25/07/2020). Cottonseeds contain 17-22\% oil, and after oil extraction, cottonseed meal (CSM) is obtained as a coproduct (Hernandez, 2016) (Fig. 2). CSM has the potential to produce $\sim 10$ MMT proteins, which could fulfil the annual protein requirements of more than half a billion people globally (Wedegaertner \& Rathore, 2015). The cottonseed protein fraction contains the highest content of salt-soluble protein (globulins: 33-63.7\%), followed by water-soluble (albumins: 20.8-32.2\%) and alkali-soluble (glutelins: 9.2-28\%) proteins (Balandrán-Quintana et al., 2019). As evidenced by a recent review, most African and Asian countries have a higher severity of malnutrition and are ranked 90-119 in the Global Hunger Index, 2018 (Rathore et al., 2020). Nevertheless, these are the highest cotton-producing nations of the world, producing more than 1000 tons of cottonseed annually (Rathore et al., 2020). Hence, the successful and efficient utilization of cottonseed as a protein source could be a game changer in mitigating malnutrition in the most severely affected countries.

\subsection{Problem of gossypol in cottonseed or cottonseed meal}

Gossypol is a toxic polyphenolic compound present throughout cotton (Gossypium hirsutum) plants, with the highest concentration (up to $2.4 \%$ on a dry weight basis) in cottonseeds. The presence of gossypol in cottonseeds or CSM limits its use both as feed for small ruminants and nonruminants and as a supplement in the human diet. The presence of this toxin in diets has several deleterious effects on the growth, development and reproductive health of animals, limiting the use of CSM as a feed in ruminants (Zhang et al., 2006a). Increasing prices of soy or animal-based proteins in Asian and African countries make CSM a more competitive and sustainable protein source for human nutrition. This protein source can be feasibly utilized if the gossypol content in CSM is reduced to a safe consumption level. The 
100 United States Food and Drug Administration (USFDA) and the World Health Organization

101 (WHO) have set the limits for free gossypol in CSM-based protein products for safe 102 utilization by nonruminants to $450 \mathrm{ppm}$.

103

104 1.4. Strategies for efficient utilization of cottonseed meal (CSM) as a source of protein

105 Initially, trials for the removal of gossypol from CSM were executed through traditional

106 physical approaches, e.g., the gland flotation technique, heat treatment, pressure cooking, and

107 the liquid cyclone process. These processes were further found to be non-feasible due to their

108 high processing costs (Rathore et al., 2020). Gamma and electron beam irradiation are some

109 of the recent physical techniques for reducing the gossypol present in the CSM. Both of these

110 irradiations caused similar effects in reducing both free and total gossypol contents in a dose-

111 dependent manner. Further molecular biology tools have been employed to reduce gossypol

112 from cottonseeds, and recently, a group of researchers working at Texas A \& M University

113 achieved ultralow gossypol concentrations in cottonseeds using molecular biology tools

114 (Rathore et al., 2020). However, there are several regulatory issues in almost all countries

115 surrounding ensuring the safe release of transgenic products (transgenic cottonseed protein)

116 into the environment and for animal and human health, making the utilization of CSM in

117 human nutrition more difficult. In another work, researchers from the New Mexico

118 Agricultural Experiment station developed a glandless cotton cultivar, 'Numex COT 15 GLS',

119 through back crossing (Zhang et al., 2016).

120 The chemical-based removal of gossypol from CSM is more feasible for its use as a

121 feed for nonruminants and as a supplement in human nutrition. The application of solvent-

122 based techniques also reduced the gossypol levels in CSM, making it appropriate as feed for

123 fisheries, poultry farms and piggeries (Rathore et al., 2020). Solvents such as ethanol and

124 acetone acidified with phosphoric acid were found to effectively reduce $90-95 \%$ of the total 
125 gossypol from the CSM (Pelitire et al., 2014). In another study, an acidified polar solvent

126 containing 2-propanol and water in a ratio of 95:5 v/v with oxalic acid was used to remove

127 gossypol from defatted CSM (Singh et al., 2020). The authors achieved a 95.43\% reduction.

128 Both acid and solvent synergistically assist in gossypol extraction. The acids assist in the

129 hydrolysis and release of the bound gossypol, while the solvents solubilize the liberated

130 gossypol. On the other hand, a biological approach using various microbial strains and

131 enzymes is a greener approach for reducing the gossypol content in CSM (Kumar et al., 132 2019a).

134 1.5. Application of cottonseed protein as a food supplement: functional characterization 135 and functional properties

136 The potential of CSP for use in human nutrition was further established by various researchers 137 through protein quality analysis. Amino acid profiling and functional property \{(water 138 holding capacity (WHC), oil holding capacity (OHC), foaming capacity (FC), foaming 139 stability (FS), emulsification activity (EA), emulsification stability (ES), and protein solubility 140 (PS) $\}$, in vitro protein digestibility (IVPD), and molecular weight analyses are a few 141 parameters that are considered important for the application of CSM in foods.

142 This review will assess the suitability of using CSP in human food by a) summarizing

143 the currently available methodologies (physical, chemical, and biological) for reducing 144 gossypol levels to legal limits, b) providing updated information on cottonseed protein 145 nutritional and functional properties, and c) reviewing CSP applications as direct and indirect 146 sources of supplements in human nutrition.

148 2. Approaches for the efficient utilization of cottonseed meal (CSM) as a protein source 149 2.1. Physical methods for the degossypolization of CSM 
150 Cottonseed contains $0.002-6.64 \%$ gossypol on a dry weight basis depending upon the cotton

151 variety and the region and climatic factors in which the cotton crop is cultivated (Gadelha et 152 al., 2014). The cotton plant has resin glands ranging from 50-400 $\mu \mathrm{m}$ in size. These glands

153 are present in plant petals, leaves, root bark, bolls and seeds and secrete gossypol (Gardner et 154 al., 1976). Gossypol is primarily found in cottonseed kernels at concentrations ranging from $1550.8-2 \%$ on a dry weight basis. It is biosynthesized in cotton plants and is classified as a 156 dimeric sesquiterpenoid since it is synthesized by dimerization of hemi-gossypol moieties 157 (Cai et al., 2010).

In the past, the extraction/removal of gossypol from cottonseed was achieved using 159 gland flotation (Boatner et al., 1949), liquid cyclone (Smith, 1971), and air classification 160 (Decossas et al., 1982) physical techniques. These methods were based on physical properties 161 such as a difference in density and physical forces such as gravitational force. In both of these method types, the glands containing gossypol were separated from the CSM (Singh et al., 2015). In the gland flotation technique, a density difference between glands containing gossypol and kernel tissues was exploited, and the flakes were agitated in a slurry of solvents 165 having a density less than that of the pigment glands. The glands were then separated by 166 flotation and obtained as a top layer, while the slurry was allowed to stand. In the liquid cyclone process, the cottonseeds were suspended in a mixed solvent with low moisture and then passed through a colloidal mill, where the glands containing gossypol were dispersed without being broken. These resin glands were separated from CSM using gravitational force 170 or sedimentation and/or flotation, depending upon the gravity of the suspending liquid (Smith, 171 1971). The liquid cyclone process was reported to produce edible CSM with less than 400 172 ppm free gossypol and more than 65\% protein (Gardner et al., 1976). After approval by the 173 USFDA, the liquid cyclone process commercially started production in 1973 in Lubbock, 174 Texas. Despite its merits, this process had limited financial feasibility and thus was non- 
175 operational after a short time period. The air classification process of gossypol separation was

176 developed as an advanced version of the liquid cyclone process. The air classification

177 technique was found to have advantages over the liquid cyclone process and was financially

178 more feasible but was never used for commercial production (Decossas et al., 1982).

179 Numerous patents were granted for the production of edible flour from cottonseeds using

180 physical methods (Rathore et al., 2020; Rathore et al., 2019).

$181 \quad$ Heat and pressure conditions (Gribbins, 1951) have also been evaluated for reducing

182 the gossypol concentrations in cottonseed kernels. It was established that pressure cooking

183 decreased the gossypol concentration by up to $91.1 \%$ in CSM (Gad \& El-Zalaki, 1980).

184 However, this method decreased the protein content in the kernels and fatty acid content in

185 the oil, limiting its application for the detoxification of CSM. Later, supercritical $\mathrm{CO}_{2}$

186 extraction was also applied to degossypolization. Supercritical $\mathrm{CO}_{2}$ extraction was employed

187 for the extraction of oil with less than $0.045 \%$ gossypol from cottonseeds (Bhattacharjee,

188 2007). Supercritical $\mathrm{CO}_{2}$ extraction is the preferred technique because it is highly efficient,

189 needs a shorter extraction time and reduces the requirement for refining, as it reduces the

190 gossypol content in the oil.

191 Recently, gamma and electron irradiation have been found to be effective in reducing 192 antinutritional factors from various plant-based sources (Nayefi et al., 2014; Shawrang et al. 193 2011; Ebrahimi-Mahmoudabad \& Taghinejad-Roudbaneh, 2011; Fatehi et al., 2020). Bahraini 194 et al. (2017) studied the effects of gamma and electron irradiation (10, 20 and $30 \mathrm{kGy}$ doses) 195 on the protein quality, chemical composition and digestibility of protein from CSM. The 196 results showed that electron irradiation at $30 \mathrm{kGy}$ resulted in a higher reduction in the free 197 gossypol content and total gossypol content compared to gamma irradiation. In another study, 198 the application of $40 \mathrm{kGy}$ electron irradiation was found to be more effective in reducing the 199 free gossypol content (82.37\%) compared to gamma irradiation (59.16\%) (Nayefi et al., 
2014). A similar reduction was also registered when applying $25 \mathrm{kGy}$ gamma and electron irradiation, making the resultant CSM fit for poultry feeding (Shawrang et al., 2011). The reduction in the gossypol concentration due to irradiation may be due to the formation of bonds between the gossypol units, their crosslinking with other compounds or the oxidation or fragmentation of the gossypol structure (Shawrang et al., 2011). Irradiation presents several advantages over the aforementioned traditional methods, such as the absence of negative environmental effects, the elimination of microbial and fungal contaminants, and the fact that the treatments cause no damage to nutrients or formation of undesirable products (Ghanbari et al., 2012). It is evident that recent physical technologies, including gamma and electron irradiation, can be effectively used to reduce the antinutritional factor gossypol to improve the nutritional profile of cottonseeds or CSM. The operation of this high-energy radiation is simple and economical compared to economically nonviable traditional approaches (air classification and gland flotation). However, gamma and electron irradiation techniques are not efficient enough to decrease the gossypol content to safer levels. In addition, the higher establishment cost and threats associated with gamma and electro-irradiation are major disadvantages of these techniques. Furthermore, the WHO has set a safer dose for gamma irradiation treatment, which is $<10 \mathrm{kGy}$, as no toxicological hazard has been reported at this level. These lower levels, however, improve the overall quality of the foods but are not sufficient for decreasing antinutritional factors from oilseeds or pulses. Hence, more focused research is needed to optimize the conditions for reducing gossypol in cottonseeds or CSM. Recently, solvent extraction has been the most commonly employed method, which is discussed in section 2.2.

\subsection{Chemical method for the degossypolization of CSM}


224 In this method, the solute CSM is dissolved in a liquid solvent, which facilitates the close 225 association of gossypol with the solvent. The choice of solvent to be utilized is dependent 226 upon the solubility of the solute in the desired solvent, effectiveness of the process, 227 nontoxicity, reusability, and low cost (Gribbins, 1951, Smith, 1971; Batson et al., 1951; 228 Thurber et al., 1954). The benefits of the solvent extraction technique include the good 229 extraction efficiency of gossypol with very low economic inputs. The factors affecting the 230 extraction technique are the particle size, moisture content, temperature, medium (acidic or 231 neutral), solvent-to-seed ratio and extraction time (Zhang et al., 2018a).

The extraction or removal of gossypol from CSM/cottonseed or cottonseed supplemented with lysine can lead to improved protein quality with increased lysine 234 availability (Gadelha et al., 2014; Saki et al., 2012). Gossypol acts as a toxic material in CSM, 235 as it binds with the lysine of the protein and is converted from free to bound gossypol. The 236 binding of gossypol to arginine and the lysine part of the meal protein occurs due to covalent 237 bonds between the gossypol molecule and epsilon amino groups (Gadelha et al., 2014), as 238 shown in Fig. 3 below.

This bound gossypol protein complex denatures the protein and imparts a dark 240 brownish-black colour to the extracted CSM, which requires further detoxification (Berardi \& 241 Frampton, 1957). It has been reported in the literature that solvent extraction of CSM 242 performed at elevated temperatures causes the binding of proteins with gossypol, degrading 243 the nutritive value of the CSP (Hron et al., 1987). Harris et al. (1949) pointed out in their 244 study that a number of useful byproducts of CSM, such as gossypol, fatty acids, protein and 245 phospholipids, can be separated and used as marketable products. Commonly employed solvents for extraction include light paraffinic petroleum 247 fractions such as pentane (boiling range, 31-36 ${ }^{\circ} \mathrm{C}$ ), hexane, heptane (boiling range, 90-99 $248{ }^{\circ} \mathrm{C}$ ) and octane (boiling range, $102-129{ }^{\circ} \mathrm{C}$ ). Nonpolar solvents such as hexane have been 
found to perform better than polar solvents. Previously, mixed solvents including commercial

250 hexane and ethyl alcohol (Liu et al., 1981), acetone-hexane (Kuk et al., 2005), acetone, 251 cyclohexane and water (Lawhon, 1969), and methylene chloride and ethanol (Jhonson \&

252 Lusas et al., 1983) were used for the extraction or removal of gossypol from CSM.

253 Researchers have also explored the removal of gossypol from CSM by multiple extractions

254 with organic solvents, viz. 1-Butanol hydrochloride, dichloromethane, 2-propanol and 1255 butanol (Liadakis et al., 1993). However, hexane is now considered a toxic solvent per 256 environmental norms, so various alternative green solvents are currently being utilized. These 257 green solvents include ethanol, methanol and isopropanol, butanol and their combinations 258 (Byrne et al., 2016; Prat et al., 2016). In addition to solvents, the use of calcium hydroxide $259(2 \%)$ and pressure-cooking treatment also reduced the free gossypol content of CSM for 260 application in poultry feed (Nagalakshmi et al., 2002). Furthermore, the addition of 261 dehydrated ferrous-sulfate to CSM at an equal amount to that of free gossypol lowered the 262 free gossypol levels to $0.0001 \%$. Dehydrated ferrous-sulfate mixed CSM was found to be 263 suitable for the consumption of broiler chickens up to 56 days of age. (Tabatabai et al., 2002). 264 Researchers have investigated the use of trichloroethylene as a solvent to minimise the 265 free gossypol content with minimal denaturation of proteins (Arnold \& Juhl, 1955). The 266 solvent extraction yielded a higher soluble protein content from CSM compared to the earlier 267 heating (cooking) method. A substantial reduction in free gossypol was obtained, with a 268 minimum reduction in water-soluble protein fractions when the extraction was carried out at 269 low temperatures of up to $50{ }^{\circ} \mathrm{C}$. Two important factors that are influenced by solvent 270 extraction of CSM are the free gossypol content and meal protein quality. The researchers 271 agreed with the findings that extraction performed at low temperatures can considerably lower 272 free gossypol contents in the residual oils and meals. Rao \& Arnold (1958) utilized ethanol as 273 a solvent to remove gossypol from cottonseeds in their pilot plant studies. They used four 
274 different concentrations of ethanol $(91.5 \%, 95.4 \%, 98 \%$ and $99.9 \%)$ and three different 275 temperatures $\left(65^{\circ} \mathrm{C}, 70{ }^{\circ} \mathrm{C}\right.$, and $\left.78.3{ }^{\circ} \mathrm{C}\right)$ with extraction times of 10 to 100 minutes. Dechary 276 et al. (1952) employed ten different solvents, viz. methanol, ethanol, dioxane, butanone, 277 acetone, isopropanol, chloroform, 1,2-di-chloroethane, perchloroethylene and 278 trichloroethylene, for the extraction of gossypol from cottonseeds in their study. The percent 279 removal of free gossypol using different solvent pairs ranged from $7.27 \%$ in the case of 280 isopropanol to $79.54 \%$ for $90 \%$ aqueous butanone. Aqueous dioxane (90\%) removed $70.54 \%$ 281 of free gossypol, and aqueous butanone (95\%) could remove $52.72 \%$ of free gossypol from 282 the flakes, while chlorine-substituted hydrocarbons were least effective in removing free 283 gossypol. The extraction temperature and amount of moisture in the extraction system 284 affected the rate of gossypol extraction when butanone-water pairs were employed as 285 solvents. This was attributable to the fact that a higher moisture content in the extraction system resulted in swelling of the flakes, which led to a decrease in the efficiency of solvent extraction. Baliga et al. (1957) found that removing the bound gossypol from meal resulted in an increase in the protein quality and its nutritive value. The bound gossypol was removed using $70 \%$ acetone and aniline without heat treatment to obtain a gossypol-CSP complex with $2903.25 \%$ bound gossypol. The insoluble, inert gossypol-protein complex reduced the loss of nutritive value of the protein. A method was reported for the preparation of cottonseed protein 292 isolate (CSPI) using meal from commercial expeller press-solvent extraction (De. Buckle et 293 al., 1979). Wan et al. (1995), in another study, employed alternate solvents for gossypol 294 removal from cottonseeds, which posed a lower health risk than hexane. Five solvents, viz. n295 heptane, neohexane, cyclopentane, and cyclohexane, were utilized in their study. All these 296 solvents were able to reduce the gossypol levels by different rates. Gossypol was removed 297 utilizing a solvent system consisting of isohexane and 5 to $25 \%$ ethanol or isopropyl alcohol 298 (IPA) (Kuk \& Hron, 1998). IPA as an extraction solvent was suggested as a promising 
alternative to hexane (Lusas et al., 1991). Highly digestible cottonseed flour was obtained using solvent extraction with acidic ethanol, having a $53.8 \%$ protein content that makes it suitable for replacing fish meal (Anderson et al., 2016).

The extraction/removal of gossypol involves a two-stage process. In the first stage, the solvent comes into contact with the solid (cottonseed/CSM). The solvent interacts with the resin glands present in the solid, solubilizing gossypol. In the second stage, intense scrubbing of the solid occurs at the solid-liquid interface, causing efficient diffusion of the solute (gossypol) into the bulk liquid phase by molecular diffusion. The extraction now becomes a mass transfer process, which is controlled by the liquid film resistance and internal solid resistance. These resistances need to be countered by the solvent to allow it to penetrate into the solid, dissolve gossypol and diffuse back to the liquid phase. This internal solid resistance is the rate-limiting step. The whole process is explained below with the help of a schematic diagram (Fig. 3). The results of solvent-based degossypolization employed by different researchers are given in Table 1.

The generally recognized as safe (GRAS) status of solvents, e.g., acetone and ethanol (Kumar et al., 2019c), for the production of foodstuffs as per council directive 2009/32/EC (2009) makes them ideal solvents for the removal of gossypol. In addition, these solvents have a higher level of solubility of gossypol, making them suitable for the extraction or removal of gossypol from CSM. The solvents are also replenished during the process, making this method more economically feasible. Findings from the scientific community also suggest that acetone is a relatively better solvent than ethanol and methanol for the extraction or removal of gossypol from CSM. This may be due to the greater interaction of acetone with the hydrophobic structure of the gossypol present in the resin glands, leading to solubilization of gossypol in the solvent system, which ultimately reduces the gossypol content in the CSM. 
323 However, more studies are required to optimize the process of degossypolization to safer

324 limits.

Fig. 3.

\section{Table 1}

\subsection{Biological method for degossypolization of CSM}

A number of physical and chemical methods have been developed by researchers for degossypolyzation, but there are several limitations associated with these methods. These methods result in an inferior active vitamin content, protein quality and feed palatability with high energy wastage (Zhang et al., 2018b). The residual solvent is difficult to remove in the

334 case of chemical degossypolization from CSM. This residual solvent is also potentially harmful to both ruminants and nonruminants. During oil recovery from CSM, the use of low temperatures and short durations is crucial to maintaining the protein quality and acceptable concentration of free gossypol. Higher temperatures often resulted in a reduced lysine content

338 in the protein. Therefore, it is necessary to develop an approach for degrading free gossypol 339 and preventing its absorption in animal systems. Studies have indicated that some 340 microorganisms belonging to the genera Candida, Torulopsis, Aspergillus, Mucor, Rhizopus 341 and Bacillus could effectively degrade free gossypol. A brief overview of free gossypol 342 detoxification by microorganisms with optimized parameters is presented in Table 2. 343 Detoxification of CSM by microbes may follow two different hypotheses - first, the 344 utilization of gossypol as a carbon source decreases the total gossypol in the CSM, and 345 second, the transformation of free gossypol to bound gossypol decreases the overall toxicity 346 of the CSM due to the action of microbes after the fermentation process (Zhang et al., 2018a). 347 Microbial detoxification of CSM can not only help achieve the desired safety criteria but can 
348 also enhance the protein and amino acid contents. Zhang et al. (2018a) found a significant 349 reduction in free and bound gossypol contents in fermented samples compared to control 350 (uninoculated) samples. A Bacillus subtilis strain found in the fluid of cow rumens was 351 isolated and characterized and found to be involved in the biodegradation of gossypol (Zhang 352 et al., 2018b). Short-term (4 days) and long-term (14 days) fermentation using yeast strains 353 was evaluated to improve the overall quality of CSM. It was found that both fermentations 354 caused an increase in both the total essential (highest increment in case of $\mathbf{M}=44 \%$ ) and total 355 nonessential amino acid contents (16-18\%). Furthermore, fermentation also resulted in the 356 reduction of gossypol by $17 \%$, which could be due to enzymatic or microbial degradation of 357 the gossypol structure (Duodu et al., 2018).

Biodegradation of polyphenolic compounds is an oxidative process that is mediated by enzymes such as oxygenases, hydroxylases, peroxidases and laccases (Mageshwaran et al., 2018). Laccases secreted by wood-degrading fungi have received substantial attention due to their involvement in the transformation of phenolic compounds into their oxidized forms. The exact mechanism behind the biological degradation of gossypol is not yet clear, but 363 Rajarathnam et al. (2001) observed the involvement of laccase in gossypol biodegradation.

364 The authors found that an enzyme extract produced from Pleurotus florida on rice straw 365 containing laccase was able to effectively degrade gossypol. An increase in the enzyme 366 concentration caused an increase in gossypol decomposition. The enzyme blank containing 367 boiled extract showed no gossypol degradation. Gossypol is a polyphenolic compound, and 368 laccase, peroxidase and polyphenol oxidase are gossypol-degrading enzymes. A mixed fungal 369 culture was grown on minimal medium containing gossypol, and its crude supernatant was 370 extracted and tested for laccase, peroxidase and polyphenol oxidase activities. Workers 371 observed higher laccase activity and lower polyphenol oxidase and peroxidase activity in the 372 crude supernatant (Mageshwaran et al., 2018). The purified supernatant had 27-35-fold 
373 higher specific activity of laccase. In the gossypol degradation experiment with crude and

374 purified enzyme extracts, the authors found that residual gossypol levels were reduced by 30

375 and $60 \%$, respectively, which explains the role of laccase in gossypol degradation. The author

376 also confirmed the identity of laccase by molecular mass determination using SDS-PAGE.

377 FTIR analysis of degraded gossypol showed a considerable reduction in the toxic aldehyde

378 stretch of gossypol.

\subsubsection{Factors affecting the degradation of gossypol in solid-state fermentation (SSF)}

Microorganism-mediated degradation of free gossypol in CSM has been well studied by many researchers using SSF. This method is affected by several input factors for reducing the gossypol concentration to a minimal amount. The initial moisture content in SSFs is one of the most important factors because it largely affects the physical properties of solid substrates. Low moisture levels during fermentation reflect poor solubility of nutrients in substrates with a lower degree of swelling, which ultimately results in poor microorganism growth (Murthy, 1999). In contrast, a higher moisture level decreases the porosity of the substrate, which limits heat and oxygen transfer during fermentation, ultimately decreasing the efficiency of free gossypol degradation (Khalaf et al., 2008; Ohno et al., 1992). Several researchers have found that an initial moisture level of $50-55 \%$ is optimal for achieving maximum free gossypol degradation (Khalaf et al., 2008). The metabolic activities of microorganisms are largely

392 affected by the $\mathrm{pH}$ value of the medium. For different fungi involved in this process, $\mathrm{pH}$ 393 values ranging from 4-6 are optimal for the maximum degradation of free gossypol (Weng \&

394 Sun, 2006; Khalaf et al., 2008). A higher pH affects the enzyme activity and growth of the organism.

A favourable incubation temperature is the key for biological degradation of gossypol 397 in a solid medium. The metabolic activities of organisms are markedly affected by 
temperature fluctuations during the process. Khalaf et al. (2008) found a significant difference in the biodegradation of free gossypol, with a maximum of $86.5 \%$ at $30{ }^{\circ} \mathrm{C}$ compared to $81 \%$ at $35 / 25^{\circ} \mathrm{C}$ and $57 \%$ at $40{ }^{\circ} \mathrm{C}$. Therefore, the incubation temperature and its regulation during the process are important, as much heat production and accumulation occurs during SSF, resulting from the poor heat dissipation property of the solid substrate. The initial load of inoculum is another crucial factor for the biodegradation of free gossypol. A lower inoculum load may produce an insufficient amount of microbial biomass, which may result in poor efficiency of gossypol biodegradation, while a heavier inoculum may produce a much higher biomass, which may lead to poor gossypol-degrading enzyme secretion (Zhang et al., 2006b). Khalaf et al. (2008) investigated the effects of various inoculum levels $\left(10^{3}-10^{9}\right.$ cells per $\left.\mathrm{g}\right)$ on free gossypol reduction and found that a concentration of $1 \times 10^{7}$ cell/g Candida tropicalis degraded a maximum of $88.6 \%$ free gossypol compared to $1 \times 10^{3}$ cell/g, which could degrade only $56 \%$. He found a decreasing trend in free gossypol as the inoculum level reached beyond $1 \times 10^{7}$ cell/g. Vellaichamy et al. (2016) used mixed cultures of fungi for degossypolization of cottonseed cakes and studied the effect of moisture, inoculum level, temperature, and time period during SSF. The optimum conditions, i.e., $70 \%$ moisture content, $30{ }^{\circ} \mathrm{C}$ temperature, $15 \%$ inoculum level, and 48 -h time period, resulted in the maximum detoxification of gossypol. Detoxification of free gossypol (83.6\%) was observed in Pleurotus sajor-caju with Saccharomyces cerevisiae, and that of bound gossypol (63.3\%) was observed in Candida tropicalis with Saccharomyces cerevisiae. In another work, a new strain of fungi isolated from soil was identified through molecular biology and morphological techniques. The Aspergillus genus demonstrated high degradation of gossypol at an optimum temperature of $30{ }^{\circ} \mathrm{C}$ and incubation time of $72 \mathrm{~h}$ (Yang et al., 2011).

Furthermore, supplementation with minerals was found to increase the fermentation efficiency (free gossypol detoxification) and protein content. Zhang et al. (2007) found an 
423 increase in the free gossypol detoxification efficiency (from 93.47 to $96.67 \%$ ) and an 424 enhancement in the crude protein content in the fermented product with the addition of 425 mineral additives. The researchers also found improved levels of lysine, methionine and 426 threonine in the crude proteins compared to the control. The addition of urea resulted in 427 decreased free gossypol levels and improved crude protein amounts. This could be due to the 428 specific role of minerals such as phosphates, which help maintain the buffering capacity of the medium and act as structural components of phospholipids, nucleic acids and coenzymes. The addition of sodium and potassium ions is responsible for maintaining the osmolarity of the medium. Potassium is a major cation found in microbial cells that acts as a cofactor for

432 phosphohexokinase (Caldwell et al., 1973; Durand \& Kawashima, 1980). Other minerals, 433 such as $\mathrm{Mn}^{2+}, \mathrm{Cu}^{2+}, \mathrm{Fe}^{2+}$ and $\mathrm{Mg}^{2+}$, also function as cofactors for several metabolic enzymes. 434 The duration of fermentation is another important factor that is mainly decided by 435 characteristics such as the growth rate of the organism and the efficiency of gossypol 436 degradation. Identifying the optimum time of fermentation is crucial. A shorter fermentation 437 time may result in incomplete utilization of the substrate and thus a reduced rate of gossypol 438 degradation, while fermentation beyond the optimum range may result in denaturation and 439 subsequent inactivation of the enzymes involved in gossypol degradation, which results from 440 interaction with the other compounds/byproducts formed during the process (Zhang et al., 441 2006). Researchers have found that the optimum time of fermentation was $60 \mathrm{~h}$ for yeast and 442 4-6 days for filamentous fungi (Wu \& Chen, 1989; Shi et al., 1998; Weng \& Sun, 2006). Degossypolization by biological methods is considered a green strategy, as it employs 444 beneficial microbes. The lower effectiveness of the method in minimising the level of 445 gossypol is the only drawback. Although this method is cheaper and efficient for free 446 gossypol degradation, this process is affected by several parameters, such as the initial 447 moisture content, $\mathrm{pH}$, incubation temperature, inoculum level, mineral additives and duration 
448 of fermentation, which need to be optimized to achieve the minimum level of antinutritional

449 factors in the resultant CSM. There is a need to discover novel strains of microbes and to 450 optimize process conditions for the effective degradation of gossypol to improve the 451 nutritional value of CSM. A combination of physical (gamma or electron irradiation) and 452 solvent-based processes or physical and biological methods, a combination of biological and 453 solvent-based processes, a combination of all three techniques may effectively remove 454 gossypol to reach safer levels for effective utilization of CSM as a sustainable protein source.

Table 2

\section{Evaluation of the quality and functional properties of cottonseed protein as a food} supplement

It is important to scientifically establish the quality of CSP. The most important factor for the analysis of protein quality is its amino acid composition. The use of CSP in human nutrition not only depends on its amino acid profile but also relies on its ability to be incorporated in foods. Hence, evaluations of functional properties such as the WHC, OHC, FC, FS, EA, ES, PS, in vitro digestibility, and molecular weight are important to establish CSP compatibility in food matrices for different types of applications (Ma et al., 2018; Tsaliki et al., 2002). In the next section, the quality of the cottonseed flour/protein will be discussed in detail, followed by various functional properties.

\subsection{Evaluation of the quality of cottonseed protein based on the amino acid profile}

\subsubsection{Amino acid profile}

471 The amino acid profile of CSM was measured by He et al. (2015). Out of the 10 essential 472 amino acids, the $\mathbf{R}$ content was the highest, amounting to $15-34 \%$ of the total protein. Other 
473

474

475

essential amino acids represented approximately $5 \%$ of the total protein, while $\mathbf{M}$ and $\mathbf{C}$ had the lowest presence (1-2\%). Of the nonessential amino acids, $\mathbf{E}$ amounted to $10 \%$ of the total protein content. Other nonessential amino acids ranged from 3 to $6 \%$ of the total protein. Similarly, the presence of $\mathbf{R}(12.47 \%)$ was the highest in essential amino acids, while $\mathbf{E}$ and $\mathbf{Q}$ (29.75\%) were highest in nonessential amino acids in cottonseed protein hydrolysate obtained from digestion by Alcalase (Song et al., 2020). In another study, CSM was evaluated for the complete profile of both nonessential (A, D, C, Q, G, P, S, and $\mathbf{Y}$ ) and essential amino acids $(\mathbf{R}, \mathbf{H}, \mathbf{I}, \mathbf{L}, \mathbf{K}, \mathbf{M}, \mathbf{F}, \mathbf{T}, \mathbf{W}$, and $\mathbf{V})$. The mean values were $1.87 \%(\mathbf{A}), 4.51 \%(\mathbf{D}), 0.79 \%(\mathbf{C})$, $9.08 \%(\mathbf{Q}), 1.99 \%(\mathbf{G}), 1.32 \%(\mathbf{P}), 2.09 \%(\mathbf{S})$, and $1.14 \%(\mathbf{Y})$ for nonessential amino acids and $5.70 \%(\mathbf{R}), 1.34 \%(\mathbf{H}), 1.48 \%(\mathbf{I}), 2.95 \%(\mathbf{L}), 2.15 \%(\mathbf{K}), 0.72 \%(\mathbf{M}), 3.0 \%(\mathbf{F}), 1.55 \%$ (T), $0.64 \%(\mathbf{W})$, and $2.15 \%(\mathbf{V})$ for essential amino acids. The CSP was fed to swine, which showed a good ileal digestibility of $80 \%$, and all the amino acids demonstrated more than 60\% digestibility (Ma et al., 2019). Delgado et al. (2019) evaluated salt and alkali-soluble protein fractions from glandless cottonseed. The authors found that essential amino acids, namely, H, I, L, K, M F, T and $\mathbf{V}$, constituted 30 and $28.1 \%$ of the total amino acids in alkali- and salt-soluble fractions, respectively. The total concentration of essential amino acids in glandless CSM was 26\%, which was higher than that in soybean protein (17\%) (Delgado et al., 2019). It is evident that cottonseeds have superior protein quality with an ideal balance of amino acids and hence could act as a sustainable alternative source of protein for human nutrition.

\subsection{Evaluation of functional properties of the cottonseed proteins}

\subsubsection{Functional properties}

The functional properties of proteins are defined as the overall physicochemical behaviour of foods during processing, storage and consumption. The WHC is a parameter that reflects the 
ability of the protein to imbibe and retain water, whereas the $\mathrm{OHC}$ is the capacity of the fat particles to bind and integrate with the nonpolar side chain of the proteins. The WHC and OHC of the different samples of CSPI ranged between $1.6-2.9 \mathrm{~g} / \mathrm{g}$ and $3.0-5.4 \mathrm{~g} / \mathrm{g}$, respectively. For soybean protein isolates, the WAC was $2.3 \mathrm{~g} / \mathrm{g}$, and the OAC was $4.5 \mathrm{~g} / \mathrm{g}$ (Ma et al., 2018; Delgado et al., 2019). This implies that the WHC and OHC follow an overlapping pattern for soybean protein. These properties influence the texture and mouthfeel attributes of food products such as baked dough, comminuted meats and analogues (Adebowale et al., 2005).

The FC is the capacity of the continuous phase of protein to hold air, whereas the FS is its ability to retain air in the continuous phase for a 30-minute duration (Tsaliki et al., 2002). The FC and FS are preferred functional properties for whipping and aeration in food systems. The FC and FS values of CSPI were evaluated for a $\mathrm{pH}$ range of 4-7. The FC and FS were minimal at $\mathrm{pH} 5$ and ranged from $15.1-31.1 \%$ and $38.8-89.0 \%$, respectively, since this $\mathrm{pH}$ was close to the isoelectric points of the proteins in CSPI. The highest FC (50.0-81.5\%) and FS (73.3-96.9\%) were observed at pH 7.0 (Ma et al., 2018; Delgado et al., 2019). Tsaliki et al. (2002) also reported the highest values of FC and FS at pH 7.0. The ability to form foam with good foaming stability makes CSP an excellent ingredient for application in ice cream, mousses, and marshmallows.

The hydrophilic and hydrophobic constituents of proteins act as effective surfaceactive agents, making them suitable for use as emulsifiers in food colloids. The potential of cottonseed proteins to develop and maintain emulsions is considered important for their multifaceted application in food systems. The emulsification properties of the proteins are evaluated on the basis of the EC and ES (Tsaliki et al., 2004). The EC is the maximum amount of oil that is emulsified under controlled conditions by a specific amount of protein. The ES is measured in terms of the amount of oil and/or cream separated from an emulsion 
523 during a certain period of time at a specific temperature and gravitational field (Pearce \&

524 Kinsella, 1978). The CSPI showed the EC varying from $13.3-23.1 \mathrm{~m}^{2} / \mathrm{g}$, whereas the ES 525 ranged between 17.3-29.6 minutes. These values were higher than the peanut protein isolate 526 EC $\left(14.8 \mathrm{~m}^{2} / \mathrm{g}\right)$ and ES (15.2 minutes). Due to the high EC and ES values, CSPI has been 527 successfully used to manufacture bakery products, sausages, sweetmeats and other emulsified 528 products (Ma et al., 2018).

The PS is the amount of protein that is dissolved in a solution under specific conditions. It is the chief determinant for use in food systems. The solubility of cottonseed protein at various $\mathrm{pH}$ values $(3-11)$ is the measure of its performance when added to food matrices. Furthermore, it is also an important indicator of protein denaturation under heating

533 and chemical processing (Horax et al., 2006). CSPI displayed maximum and minimum PS

534 values at $\mathrm{pH} 11$ and $\mathrm{pH}$ 5, respectively. Soybean protein isolates also showed a similar 535 solubility profile, with a maximum at $\mathrm{pH} 11$. It was suggested that the weakened interaction 536 between water and protein resulted in increased protein-protein interactions, which ultimately 537 caused aggregation and precipitation of CSPI (Ma et al., 2018).

\subsubsection{In vitro protein digestibility (IVPD)}

540 Protein digestibility is an important factor in determining protein availability for absorption in

541 the intestinal tract. IVPD is a universally accepted assay to estimate the parameters related to 542 protein digestibility. The IVPD assay mimics conditions similar to those of the human 543 digestive tract by using different proteolytic enzymes (e.g., the papain system or pepsin544 pancreatin enzyme system). This helps analyse the amount of hydrolysed proteins (Hur et al., 545 2011). This assay is more rapid, affordable and equivalently efficient than other in vivo 546 assays. The existing literature is focused on animal digestion of CSM (Can et al., 2011; Heim $547 \&$ Krebs, 2018; Yue et al., 2007). There is, therefore, a research gap for future work that could 
548 address the digestibility of CSM or cottonseed protein from the perspective of human 549 digestion.

\subsubsection{Molecular weight}

552 The most commonly used technique for molecular size analysis of cottonseed protein is

553 sodium dodecyl sulfate-polyacrylamide gel electrophoresis (SDS-PAGE). This technique 554 separates protein polypeptides on the basis of their molecular size. CSPIs from seven different sources were compared with those of peanut and soybean protein isolates through molecular weight profiling using SDS-PAGE under reducing and nonreducing conditions. Under nonreducing conditions, CSPI showed two high-intensity bands at 50 and $45 \mathrm{kDa}$, implying

558 that these two fractions are the main constituents (Delgado et al., 2019; Ma et al., 2018).

559 Under nonreducing conditions, these protein subunits include the salt soluble fraction 560 (globulins), i.e., globulin 9S (Sun et al., 2012). In contrast, reducing conditions showed that many minor protein bands appeared between 35 and $14 \mathrm{kDa}$, suggesting the existence of

562 disulfide bonds between the peptides of the CSPIs (Delgado et al., 2019; Ma et al., 2018). 563 These protein subunits include both salt- (globulins 5S: 24 and $22 \mathrm{kDa}$ ) and water-soluble 564 fractions (albumins; albumin 2S: 20, 15 and $14 \mathrm{kDa}$ ) (Sun et al., 2012). In another study, out 565 of 4 protein fractions, globulins reached a maximum (33-63.7\%), followed by albumins $566(20.8-32.2 \%)$, glutelins (9.1-28\%), and prolamins at the lowest concentration (Singh \& Kaur, 567 2019). The molecular weights of polypeptides in cottonseed protein from Gossypium 568 arboreum and Gossypium hirsutum lines were found to be in the range of 10-122 kDa (Singh $569 \&$ Kaur, 2019). The molecular weight of the alkali-soluble protein fraction varied from 10-54 $570 \mathrm{kDa}$ in both species. Water- and alkali-soluble cottonseed protein profiling was performed by 571 He et al. (2018). They found molecular weights of CSP in the range of 10-381 kDa. 
573

574

575

576

577

578

579

580

581

582

583

584

585

586

587

588

589

590

591 592 films.

\subsubsection{Rheological properties}

The rheological behaviour of protein helps with the modelling and design of products, the development of food products, sensory evaluation, quality control, acceptability to consumers and long-term stability (Erçelebi \& Ibanoğlu, 2009). Various protein extraction processes disrupt chemical bonds, such as electrostatic interactions, hydrogen bonds, hydrophobic, hydrophilic and covalent bonds, and structure and aggregations of protein molecules and affect the viscosity and rheological behaviour of proteins (Turker Saricaoglu, 2019). He et al. (2016) studied the rheological behaviour of CSM, CSPI and water-washed CSM at different $\mathrm{pH}$ values. The adhesive strength of CSPI decreases with storage time and is ineffective in water-washed CSM at $\mathrm{pH} 6,7.5$ and 9. The viscosity depends on the shear rate, and the highest viscosity was obtained at $\mathrm{pH} 9$ for water-washed CSM and $\mathrm{pH} 7.5$ for CSPI. The viscosity remained unaltered in CSPI, but the viscosity of water-washed CSM increased with time. The storage and loss modulus values are two viscosity parameters that indicate the strength of gels. A high storage modulus increases the aggregation of CSPI molecules due to repulsive force reduction. A high $\mathrm{pH}$ and low ionic strength form a gel with thick strands and large aggregates and pores; however, a low $\mathrm{pH}$ and high ionic strength form a gel with a fine structure and small aggregates and pores. The ionic strength $(\mathrm{NaCl})$ and $\mathrm{pH}$ affected the gel formation and rheological behaviour of CSPI (Zhou et al., 2015). The rheological behaviour of CSPIs provides many applications in food, such as protein-based gels and edible packaging

593

\subsubsection{Surface hydrophobicity (SH)}

595 The SH represents the number of hydrophobic groups present on the surface of a protein. The surface hydrophobicity shows the subsequent aggregation and partial denaturation of

597 hydrophobic groups of protein molecules. The SH increases with the number of hydrophobic 
groups largely exposed on the surface. Ma et al. (2018) studied the SH of CSM and CSPI extracted with different methods. The maximal SH was obtained in the proteins isolated using subcritical extraction from CSM (727.5), followed by insect-resistant CSM (615.7), colour CSM (561.7), XinLiang CSM (128.1), YiHai CSM (120.5), JingGu CSM (110.5) and Tiankang CSM (103.7). A higher SH was found in soybean protein isolates than in proteins isolated from CSM with different extraction methods. The results suggested that the hotpressing method of protein extraction unfolds CSP aggregations, and other methods of CSP extraction cause conformational changes. The $\mathrm{SH}$ of protein is closely related to its emulsifying properties and protein solubility. The SH of CSP enhances the emulsifying activity of CSP due to strong bonding between oil droplets and emulsifiers. CSPIs with better surface hydrophobicity have improved uses in the food industry.

The amino acid profile of the CSP showed a balanced ratio of essential amino acids, with the highest content of $\mathbf{R}$ amino acids. The evaluation of various food functional properties of CSP established the application of CSP in numerous food products as a preservative, foaming agent, and emulsifier. The predominance of salt and water-soluble proteins with excellent rheological properties further suggests the potential application of CSPs in foods.

\subsubsection{Surface, structure, and peptide characterization of cottonseed protein (CSP)}

The functional properties of protein isolates depend on the chemical composition and other surface characteristics. The surface properties of CSM and water-soluble and alkali-soluble CSP were evaluated by He et al. (2017) using scanning electron microscopy (SEM), energy dispersive spectrometry (EDS), and X-ray diffraction. Alkali- and water-soluble proteins showed similar surface properties. SEM analysis of CSP showed irregular wrinkling with light spongy porous structures, which was attributed to the presence of polysaccharide 
623

624

625

626

627

628

629

630

631

632

633

634

635

636

637

638

639

640

641

642

643

644

645

646

647

components. Other CSPs by the same authors reflected flatter areas, tight surfaces and sharp angles (Kumar et al., 2021). EDS analysis of CSP reflected the presence of $\mathrm{Ca}, \mathrm{Cu}, \mathrm{Na}, \mathrm{Mg}$, $\mathrm{K}$, and $\mathrm{P}$, whereas $\mathrm{C}$ and $\mathrm{O}$ were detected as major elements due to the organic nature of the sample. The XRD pattern reflected the structure of CSP, which was reported by the same authors. XRD showed peaks at $2 \theta$ of approximately 9.4 and $20^{\circ}$. This XRD pattern was found to be similar to that of soybean protein powder, reflecting $\alpha$-helix and $\beta$-sheet structures of protein molecules, respectively (He et al., 2018). The water- and alkali-soluble CSPs were extracted sequentially, and mass spectrometric analysis showed the presence of 70 polypeptides with molecular weights ranging from 10 to $381 \mathrm{kDa}$. The most abundant peptides in the fraction were legumin $\mathrm{A}(58 \mathrm{kDa}), \mathrm{B}(59 \mathrm{kDa})$, vicilin $\mathrm{C} 72(70 \mathrm{kDa})$, vicilin GC72-A (71 kDa), and vicilin-like antimicrobial peptides (62 kDa) (He et al., 2018). This information is crucial for the application of CSP as a functional food additive.

\section{Food and non-food application of cottonseed protein}

Plant based-proteins are gaining importance due to their renewable and sustainable nature. Kumar et al., (2021a) summarized various methods of extraction of plant proteins for possible utilization as food supplement. Cottonseeds are traditionally used as the chief ingredient in a widely popular Indian ethnic beverage popularly known as Paruthi Paal (Kumar, 2019b).

Owing to the presence of superior-quality proteins, essential fatty acids and sugars, CSP is regarded as a 'triple nutrient'. It has been reported to have many health benefits, such as healing stomach ulcers, preventing polycystic ovary syndrome, regulating the menstrual cycle, modulating blood pressure, and improving neurological health. Food products made from cottonseeds were served to soldiers at the time of World War II due to the unavailability of various other nutritional sources. Additionally, cottonseed soup has been traditionally used as food in India, Pakistan, and Bangladesh in the Asian continent and in Nigeria, Uganda, 
648 Burkina Faso, Zambia, Tanzania, and ten other countries in the African continent. These

649 countries are chief cotton producers but at the same time face the menace of protein calorie

650 malnutrition (Kumar, 2019b). The use of CSP either directly or indirectly in place of animal

651 protein can help overcome the problem of malnutrition. Apart from food applications, there

652 are numerous non-food applications of CSP or CSM. Applications such as packaging (films

653 and coating) of agriculturally based products, adhesives, bioplastic, interfacial and

654 emulsifying applications, hydrogels, and other applications are discussed in section 4.2.

655

\subsection{Food applications of cottonseed meal (CSM) and cottonseed protein (CSP)}

\subsubsection{CSP as a direct source of protein for human nutrition}

658 CSPI and flours have been widely used to develop various food products and are prevalently

659 accepted as nutritional and functional ingredients in baked foods and meat products (Zhuge et 660 al., 1988). In the past, Cater et al. (1977) established the potential of CSPs in a variety of food 661 systems. The authors reported that CSP had been used in the US as a food additive since the 662 1930s. Less than 5\% of defatted cottonseed flour was added to cookies, doughnuts and 663 chocolate candies due to the functional properties of the CSP rather than its nutritional 664 attributes. This was also confirmed by Spadaro et al. (1979), who referred to a product named 665 "Proflo", which was mainly used to give functional characteristics to bakery and 666 confectionery products. Both Spadaro et al. (1979) and Cater et al. (1977) reported in the late 6671950 s and the 1960s that a low-cost and highly nutritious food product called INCAP 668 vegetable mixture or "Incaparina" was popular in Guatemala and Colombia and used 2 669 million pounds of cottonseed in 1964.

670 Spadaro et al. (1979) reviewed numerous food applications of CSP concentrate,

671 including meat products (such as beef burgers, meatballs, fresh sausages and frankfurters), 672 extruded cereal-type products (such as snacks and textured vegetable proteins), and baked 
673 goods (such as cookies, doughnuts, cakes and breads). De Buckle et al. (1979) also reported

674 that cottonseed flours could be texturized in a way similar to that of soybean flour,

675 simultaneously reducing the free gossypol content to safe levels. The same authors also

676 produced a CSPI with $90 \%$ protein, which had a white creamy colour and a bland flavour.

677 Zhuge et al. (1988) processed CSM through extrusion, drying, grinding and air classification

678 and obtained a low-gossypol product. The final coarse product had a particle size larger than

$67984 \mu \mathrm{m}$ and a protein content of 36.6-45.2\%. Alford et al. (1996) reviewed several human

680 studies using dietary CSPs and concluded that these proteins assist in ameliorating the health

681 of malnourished or undernourished children and adult women. In addition to CSM, glandless

682 cottonseed kernels were used for the development of the nut-like snack 'Tamunuts' using a

683 dry roasting technique standardized by Texas A \& M University, Texas, USA. These nuts

684 were preferred over 'soy nuts' by the tasting panel (Dowd, 2015; Lusas et al., 1978; Rathore

685 et al., 2020).

686 Although much research was carried out in the late 1970s and 1980s on CSP and its

687 incorporation into foods, interest in this protein gradually declined. Only a few studies have

688 been conducted on cottonseed as a food since the early 2000s, and a few of these studies on

689 beef and extruded snacks are elaborated upon below. CSM was incorporated into ground beef

690 at $0-3 \%$ (Rhee et al., 2001). The 3\% CSM added to beef served as a highly effective

691 antioxidant, decreasing 2-thiobarbituric acid-reactive substances (TBARS) by 77-91\%

692 compared to the cottonseed-free control beef. Reyes-Jáquez et al. (2012) produced extruded

693 snacks using CSM. The optimal inclusion level was found to be 10\% CSM, and the resulting

694 snack had less fat and more protein than the control snacks. In another study, the peptide

695 fractions obtained from the alcalase enzyme treatment of CSP demonstrated novel properties.

696 It was found that the higher content of positively charged amino acids (K, R \& $\mathbf{H})$ and lower

697 content of negatively charged amino acids (D, E) resulted in higher antioxidant and 
698 antibacterial activities. Later, cottonseed protein hydrolysates underwent in vitro digestion

699 (Song et al., 2020). These isolates showed no antibacterial activity before or after in vitro 700 digestion, although they exhibited some antioxidant activities. One peptide retained high 701 natural antibacterial activity even after 6 h of digestion (Song et al., 2020). He et al. (2020) 702 evaluated water-soluble fractions of lab scale-produced CSP from glandless, glanded, and 703 pilot-scale-produced glanded CSP. Pilot scale-produced protein showed the maximum 704 antioxidant activity using the DPPH assay (70.6\%), while both lab scale-processed fractions 705 exhibited comparable antioxidant properties. The superior antioxidant activity of pilot scaleproduced protein fractions was higher due to the presence of an increased number of peptide fragments with exposed hydrophobic amino acids $(\mathbf{W})$. The improved hydrophobic nature of

708 the pilot scale-produced protein peptides allowed them to act as antioxidants by improving their solubility in nonpolar solvents, subsequently enhancing their interactions with free radicals (Kim et al., 2007). These findings are valuable, as they show the potential to develop

711 peptides that could be used in functional food formulations from low-value cottonseeds. In a study, detoxified CSP protein obtained from alkali-salt based method was evaluated critical quality standards as per the guidelines of Food Safety and Standards Regulation, 2011 (Kumar et al., 2021b). It was concluded that lyophilised protein powder obtained at optimised conditions have higher crude protein content $(93.1 \%)$, lower free $(0.03 \%)$ and total gossypol $(0.27 \%)$ with no presence of food borne pathogens. It is evident that cottonseeds have a balanced ratio of amino acids and can be a sustainable source of protein in countries where 718 cotton is grown as the predominant crop.

4.1.2. Cottonseed/cottonseed meal (CSM) as an indirect source of protein for human nutrition

722 In addition to having direct applications as a food supplement in human nutrition, 
723

724

725

726

degossypolized CSM can indirectly be used for alleviating protein energy malnutrition. Lowgossypol CSM can be effectively used as feed in both the poultry and aquaculture industries. These animals can effectively convert feed protein into edible animal protein (Rathore et al. 2020). Several protein conversion ratios (PCRs: feed protein used/edible animal protein produced) have been established for the conversion of ultralow gossypol CSP into animalbased protein for human nutrition. For example, poultry for egg production is reported as the most efficient means of converting plant protein to edible animal protein with a PCR of 2.6. Chicken meat production with a PCR of 4.7 is superior to that of other animal-based protein sources, such as pigs (5.7), fish (4.6-5.7) and prawns (7.7) (Rathore et al., 2020). Several authors have recently investigated the effect of CSP, CSF, CSC and CSPI on feed diets in aquacultural species (Anderson et al, 2016; Wang et al, 2020; Ye et al, 2020; Yin et al, 2018), pigs (Li et al, 2019), and lambs (Moretti et al, 2019). Delgado et al., (2021) studied the functional properties of the extruded shrimp feed containing CSM with ultra-low gossypol content. It was concluded that use of ultra-low gossypol CSM as fishmeal substitute is a feasible alternative to reduce the costs of the shrimp feed while showing a balanced content of minerals, amino acids, protein, and essential fatty acids. In an independent study, degossypolised CSP was evaluated for the energy and nutrient digestibility and as a source of supplement in the nursery pigs (Wang et al., 2019). It was concluded that degossypolised CSP can be utilised as a supplement in nursery pig diets at the proportion of 5 and $10 \%$ within two and after two-weeks of weaning, respectively. CSP can be effectively metabolized by poultry, fish, and pigs to convert plant protein into animal protein. Hence, cottonseed may serve as an indirect source of protein for nonvegetarians. The conversion of CSP into animal protein also reduces the risk of gossypol, which is otherwise associated with direct consumption of CSP.

\subsection{Nonfood application of cottonseed meal (CSM) and cottonseed protein (CSP)}


748 The mechanical properties, water solubility, plasticizing characteristics, crosslinking 749 behaviour, and 3D structure of cottonseed protein contribute to many non-food applications. 750 These applications include packaging, adhesive, bioplastic, hydrogel, interfacial material, and 751 emulsifying applications (Cheng et al., 2020). The application of CSP as a wood adhesive has 752 been established in the recent past, and it has been reported that the combination of CSP and 753 phosphoric acid is even more effective as a wood adhesive than soy protein (Cheng et al., 754 2017). Li et al. (2019) evaluated the effects of dipotassium hydrogen phosphate, phosphoric 755 acid, calcium oxide and calcium hydrogen phosphate on the adhesive strength of CSP at 20 to $80 \mathrm{mM}$ concentrations. The authors found that CSP with $40 \mathrm{mM}$ phosphoric acid treatment resulted in higher adhesive strength with high water resistance, indicating CSP as an eco758 friendly adhesive in the wood industry. CSM in combination with urea formaldehyde is also 759 used as a green and environmentally friendly adhesive in wood-based composites (Liu et al., 2018). Cheng et al. (2017) used CSP in combination with different acids as a paper additive 761 and studied the resulting characteristics by Fourier transform-infrared (FTIR) spectroscopy and SEM analysis. The results suggested that CSP interacted with acids and paper fibres to 763 enhance the strength. Similarly, CSP was evaluated by thermogravimetric analysis and SEM 764 and FTIR analysis to study its characteristics as a strength enhancer. The results suggest that 765 CSPs interact with cotton fibres and increase the strength in nonwoven fabric (Villalpando et al., 2018). Vigorous blending enhances water- and alkali-soluble CSP recovery and quality, 767 providing good characteristics and enabling industrial applications (He et al., 2013). Films and coatings are used in the packaging of Agri-based products such fruits and 769 vegetables to enhance their shelf life. Glycerol, urea and aldehyde were used as additives in 770 bioplastic preparations. These crosslinking agents enhance the mechanical strength, water 771 absorption resistance, and thermal stability of the products (Cheng et al., 2020). CSP was 772 plasticized with glycerol and embedded with biodegradable material through extrusion and 
773 thermosetting. The study established that glycerol plays a crucial role in making CSP

774 thermoplastic through a $54{ }^{\circ} \mathrm{C}$ increase in the thermal denaturation temperature. Attention to 775 the development of edible protein films has increased recently surrounding applications in 776 food packaging (Chen et al., 2019).

\section{$778 \quad 5$. Food safety and regulatory issues}

779 Food Safety and Standards Regulations (FSSR), 2011 (version IV, published on 9/11/2017), suggests that cottonseed flour or protein can be utilized as a food ingredient if it follows certain standards. These quality parameters include the moisture content $(<8 \%)$, crude protein (> 47\%), free gossypol content $(<0.06 \%)$, total gossypol content $(<1.2 \%)$, ash insoluble content $(<0.35 \%)$, total ash content $(<5.0 \%)$, available lysine content greater than $3.6 \mathrm{~g} / 100$

$784 \mathrm{~g}$ of crude protein, crude fibre content $(<5.0 \%)$, and fat content less than $1.5 \%$ dry weight. In 785 addition to these parameters, the microbial count, i.e., the total bacterial count, should be less than 50000/g. The Coliform bacterial count should be less than 10/g, and the Salmonella bacterial count should be nil in $25 \mathrm{~g}$. The European Union has provided specific guidelines on the concentration of gossypol for applications as feed for ruminants and nonruminants. The maximum free gossypol concentration for cottonseed is $5,000 \mathrm{ppm}$, that for CSM or cake is $1,200 \mathrm{ppm}$, that for laying hens and piglets is $20 \mathrm{ppm}$, that for rabbits and pigs is $60 \mathrm{ppm}$, that

791 for poultry and calves is $100 \mathrm{ppm}$ and that for cattle, sheep, and goats is $500 \mathrm{ppm}$. According 792 to the USFDA, CSPs and their food products can be considered edible if they contain less 793 than $0.045 \%$ and $0.8 \%$ free gossypol and bound gossypol, respectively (Ma et al., 2018).

794 Numerous pulse and oilseed proteins can act as potent allergens, causing an undesirable 795 immune response in susceptible individuals. To address this concern, the USFDA has 796 identified 8 major allergens, e.g., eggs, milk, shellfish, crustaceans, peanuts, tree nuts, 797 soybean, and wheat, that cause $90 \%$ of allergic reactions in susceptible individuals (Rathore et 
al., 2020). These rules are followed by most countries, and allergens need to be compulsorily mentioned by food manufacturers on food labels. In contrast, cottonseed is not reported to instigate any allergic or hypersensitive immune response. This is because its protein profile is very similar to the proteins present in a variety of legumes, peanuts, and tree nuts. All the mentioned quality parameters are achievable by following eco-friendly and cost-effective methods for the extraction of protein from CSM. The protein recovered can potentially be used as a supplement in human nutrition.

\section{Conclusion and future perspectives}

Gossypol chemically binds to cottonseed proteins during cottonseed processing and reduces their nutritive value. Different separation methods, e.g., physical, chemical and biological, have been used to reduce or extract gossypol from cottonseeds. Using biotechnological and breeding strategies for degossypolization strips the plants of their major defence against insect and pest predation. Thus, current efforts are focused on reducing gossypol levels in cottonseed products after harvesting and decreasing their oral bioavailability in feeds. The separation of gossypol from CSM can render a large amount of high-quality edible protein to be effectively utilized as animal rations and for human consumption. Toxicological studies have revealed that gossypol is fatal for animals and young ruminants if it is present in animal feed in large amounts beyond the permissible limit of 450 ppm. Gamma irradiation is emerging as a novel degossypolyzation physical methodology, replacing traditional approaches (gland flotation, cyclone, heat and pressure treatment and $\mathrm{CO}_{2}$ supercritical extraction) burdened with some drawbacks (low protein yields and quality, inefficient detoxification, use of toxic reagents and environmental risks). Gamma irradiation is a greener technique that preserves the protein quality. However, gossypol contents below the permissible limit have not yet been reached, and therefore solvent extraction remains the 
823

824

The work has been supported by the Science for Equity, Empowerment and Development

844 Division of Department of Science and Technology, Government of India, under grant 845

method of choice, despite the presence of residual solvent in CSP. The use of gossypoldegrading microorganisms appears promising but is still in need of process optimization.

Recent advances in feed technology have resulted in lower gossypol levels in feed and higher awareness of acute gossypol poisoning. Thus, the development of sustainable detoxification techniques and the isolation of edible high-quality proteins should be the focus of future research. A number of recent techniques, such as ultrafine grinding and pulsed magnetic field treatment, achieved an $83 \%$ reduction in the free gossypol content. Other nonconventional technologies, including microwave-assisted, ultrasound-assisted, subcritical or supercritical removal of gossypol, can be used in the future to further improve the utilization of CSM for human nutrition. Functional characterization of CSP indicates a superior amino acid profile with excellent functional properties, making it a suitable candidate for application in the food industry. Nevertheless, interest in this protein has decreased since the 2000s. Emerging greener degossypolization strategies seem to justify future revisitation of the use of CSP as a direct or indirect source of protein for the alleviation of hunger, which will also assist in achieving the UN sustainable development goals.

\section{Conflict of interest}

\section{None}

\section{Acknowledgement} no. SP/YO/476/2018. 
846

847

848

849

850

851

852

853

854

855

856

857

858

859

860

861

862

863

864

865

866

867

868

869

\section{References}

Adebowale, Y. A., Adeyemi, I. A., \& Oshodi, A. A. (2005). Functional and physicochemical properties of flours of six Mucuna species. African Journal of Biotechnology, 4(12), $1461-1468$.

Alford, B. B., Liepa, G. U., \& Vanbeber, A. D. (1996). Cottonseed protein: What does the future hold? Plant Foods for Human Nutrition, 49(1), 1-11.

Anderson, A. D., Alam, M. S., Watanabe, W. O., Carroll, P. M., Wedegaertner, T.C., \& Dowd, M. K. (2016). Full replacement of menhaden fish meal protein by lowgossypol cottonseed flour protein in the diet of juvenile black sea bass Centropristis striata, 464, 618-628.

Arnold, L. K., \& Juhl, W. G. (1955). The reduction of free gossypol in cottonseed flakes during solvent extraction. Journal of the American Oil Chemists' Society, 32(3), 151152.

Bahraini, Z., Salari, S., Sari, M., Fayazi, J., \& Behgar, M. (2017). Effect of radiation on chemical composition and protein quality of cottonseed meal. Animal Science Journal, 88(9), 1425-1435.

Balandrán-Quintana, R. R., Mendoza-Wilson, A. M., Montfort, G. R. C., \& Huerta-Ocampo, J. Á. (2019). Plant-Based Proteins. In Proteins: Sustainable Source, Processing and Applications, 97-130. Academic Press.

Baliga, B. P. \& Carl, M. L. (1957). Journal of the American Oil Chemists'Society, 34 (1), 2124.

Batson, D. M., Thurbur, F. H., \& Altschul, A. M. (1951). The effect of screw-press and hydraulic-press processing conditions on pigment glands in cottonseed, Journal of the American Oil Chemists' Society, 28(11), 468-472. 
870 Berardi, L. C., \& Frampton, V. L., (1957). Note on gossypol and its relation to color fixation in cottonseed oil. Journal of the American Oil Chemists' Society, 34 (8) 399-401.

872 Bhattacharjee, P. (2007). Supercritical carbon dioxide extraction of cottonseed oil. Journal of Food Engginering, 79, 892-898.

874

875

876

877

878

879

880

881

882

883

884

885

886

887

888

889

890

891

892

Black and Sesikiran, The Double Burden of Childhood Undernutrition and Overweight Globally and the Situation in South Asia, web source: https://www.nestle.com/sites/default/files/assetlibrary/documents/creating\%20shared\%20value/expert-opinions.pdf accessed on $\underline{25 / 12 / 2020}$

Boatner, C.H., Hall, C. M., \& Merifield A. L. (1949). Inventors; Heavy gravity liquid separation of cottonseed, U S Patent 2,482,141, September 20.

Byrne, F. P., Jin, S., Paggiola, G., Petchey, T. H. M., Clark, J. H., Farmer, T. J., Hunt, A. J., McElroy, C. R., \& Sherwood, J. (2016). Tools and techniques for solvent selection: green solvent selection guides. Sustainable Chemical Processes, 4(7), 1-24.

Cai, Y., Xie, Y., \& Liu, J. (2010). Glandless seed and glanded plant research in cotton. A review. Agronomy for Sustainable Development, 30(1), 181-190.

Caldwell, D. R., Keeney, M., Barton, J. S., Kelley, J. F., (1973). Sodium and other inorganic growth requirements of Bacteroides amylophilus. Journal of Bacteriology, 114, 782789.

Can, A., Hummel, J., Denek, N., \& Südekum, K.-H. (2011). Effects of non-enzymatic browning reaction intensity on in vitro ruminal protein degradation and intestinal protein digestion of soybean and cottonseed meals. Animal Feed Science and Technology, 163(2-4), 255-259. 
893 Cater, C. M., Mattil, K. F., Meinke, W. W., Taranto, M. V., Lawhon, J. T., \& Alford, B. B.

894

895

896

897

898

899

900

901

902

903

904

905

906

907

908

909

910

911

912

913

914

915 (1977). Cottonseed protein food products. Journal of the American Oil Chemists' Society, 54(2), A90-A93.

Cheng, H. N., Ford, C., Dowd, M. K., \& He, Z. (2017). Effects of phosphorus-containing additives on soy and cottonseed protein as wood adhesives. International Journal of Adhesion and Adhesives, 77, 51-57.

Cheng, H. N., He, Z., Ford, C., Wyckoff, W., \& Wu, Q. (2020). A Review of Cottonseed Protein Chemistry and Non-Food Applications. Sustainable Chemistry, 1(3), 256-274.

Cheng, H. N., Villalpando, A., Easson, M. W., \& Dowd, M. K. (2017). Characterization of cottonseed protein isolate as a paper additive. International Journal of Polymer Analysis and Characterization, 22(8), 699-708.

Council directive 2009/32/EC on the approximation of the laws of the Member States on extraction solvents used in the production of foodstuffs and food ingredients. (2009). Official Journal of the European Union, L141/3.

De Buckle, T. S., Zapata, L. E., Silva, G., Cabrera, J. A., De Sandoval, A. M., Ben-Gera, I., ...\& Shomer, I. (1979). Two food applications of cottonseed flours and meals. Journal of the American Oil Chemists'Society, 56(3Part2), 297-299.

Dechary, J. M., Kupperman, R. P., Thurber, F. H., \& Altschul, A. M. (1952). Removal of gossypol from cottonseed by solvent extraction procedures. Journal of the American Oil Chemists Society, 29(8), 339-341.

Decossas, K. M., Kadan, R. S., Spadaro, J. J., Ziegler, G. M., \& Freeman, D.W. (1982). Edible cottonseed flour by air classification of glanded seed: cost analysis. Journal of the American Oil Chemists'Society, 59, 488-494. 
Delgado, E., Valles-Rosales, D. J., Flores, N. C., \& Reyes-Jáquez, D. (2021). Evaluation of fish oil content and cottonseed meal with ultralow gossypol content on the functional properties of an extruded shrimp feed. Aquaculture Reports, 19, 100588.

Delgado, E., Valverde- Quiroz, L., Lopez, D., Cooke, P., Valles- Rosales, D., \& Flores, N. (2019). Characterization of Soluble Glandless Cottonseed Meal Proteins Based on Electrophoresis, Functional Properties, and Microscopic Structure. Journal of Food Science, 84(10), 2820-2830.

Dowd, M. K. (2015). Seed. In Cotton, Agronomy Monograph 57; Fang, D. D. \& Percy, R.G., Eds. American Society of Agronomy, Inc., Crop Science Society of America, Inc., and Soil Science Society of America, Inc.: Madison, WI, 745-782.

Duodu, C. P., Adjei-Boateng, D., Edziyie, R. E., Agbo, N. W., Owusu-Boateng, G., Larsen, B. K., \& Skov, P. V. (2018). Processing techniques of selected oilseed by-products of potential use in animal feed: Effects on proximate nutrient composition, amino acid profile and antinutrients. Animal Nutrition, 4(4), 442-451.

Durand, M., \& Kawashima, R. (1980). Influence of minerals in rumen microbial digestion. In 'Digestive physiology and metabolism in ruminants'.(Eds Y Ruckebush, P Thivend) pp. $375-408$.

Ebrahimi-Mahmoudabad, S. R., \& Taghinejad-Roudbaneh, M. (2011). Investigation of electron beam irradiation effects on anti-nutritional factors, chemical composition and digestion kinetics of whole cottonseed, soybean and canola seeds. Radiation Physics and Chemistry, 80(12), 1441-1447.

Erçelebi, E. A., \& Ibanoğlu, E. (2009). Rheological properties of whey protein isolate stabilized emulsions with pectin and guar gum. European Food Research and Technology, 229(2), 281-286. 
940 Fatehi, P., Assadi-Alamouti, A., Behgar, M., \& Norouzian, M. A. (2020). Effect of electron

941

942

943

944

945

946

947

948

949

950

951

952

953

954

955

956

957

958

959

960

961

962 irradiation on some physical, chemical and digestion properties of pistachio byproducts. Radiation Physics and Chemistry, 108921.

Gad, T. E., \& El-Zalaki, E. M. (1980). Effect of various pressure cooking conditions on gossypol content of cottonseed meal and oil. Fette, Seifen, Anstrichmittel, 82(11), $450-453$.

Gadelha, I. C. N., Fonseca, N. B. S., Oloris, S. C. S., Melo, M. M., \& Soto-Blanco, B. (2014). Gossypol Toxicity from Cottonseed Products. The Scientific World Journal, $1-11$.

Gardner, H. K., Hron, R. J., Vix, H. L. E. (1976). Removal of pigment glands (gossypol) from cottonseed. Cereal Chemistry, 53, 549-60.

Ghanbari, F., Ghoorchi, T, Shawrang, P., Mansouri, H., \& Torbati-Nejad, N. M. (2012). Comparison of electron beam and gamma ray irradiations effects on ruminal crude protein and amino acid degradation kinetics, and in vitro digestibility of cottonseed meal. Radiation Physics and Chemistry, 81, 672-678.

Gribbins, G. H. (1951). The reduction of free gossypol in cottonseed by pressure cooking, Journal of American Oil and Chemist's Society, 28, 41-45.

Harris, W. D., Hayward, J. W., \& Lamb, R. A. (1949). Isopropanol as a solvent for extraction of cottonseed oil. II. Separation of purified oil from miscella. Journal of the American Oil Chemists' Society, 26(12), 719-723.

He, Z., Chapital, D. C., \& Cheng, H. N. (2016). Effects of pH and storage time on the adhesive and rheological properties of cottonseed meal-based products. Journal of Applied Polymer Science, 133(27). 
963 He, Z., Cheng, H. N., Olanya, O. M., Uknalis, J., Zhang, X., Koplitz, B. D., \& He, J. (2017).

964

965

966

967

968

969

970

971

972

973

974

975

976

977

978

979

980

981

982

983

984

985

986 Surface characterization of cottonseed meal products by SEM, SEM-EDS, XRD and XPS analysis. JMSR, 7(1), 28-40.

He, Z., Zhang, D., \& Cao, H. (2018). Protein profiling of water and alkali soluble cottonseed protein isolates. Scientific reports, 8(1), 1-9.

He, Z., Zhang, D., \& Modesto Olanya, O. (2020). Antioxidant activities of the water-soluble fractions of glandless and glanded cottonseed protein. Food Chemistry, 126907.

He, Z., Zhang, H., \& Olk, D. C. (2015). Chemical Composition of Defatted Cottonseed and Soy Meal Products. PLOS ONE, 10(6), e0129933.

Heim, R. A. L., \& Krebs, G. L. (2018). Ruminal protein digestibility of Australian produced oilseed meals. Animal Production Science.

Hernandez, E. (2016). Cottonseed: Overview. In C. Wrigley, H. Corke, K. Seetharaman \& J. Faubion (Eds.), Encyclopedia of Food Grains (Second Edition) (pp. 242-246). Oxford: Academic Press.

Horax, R., Hettiarachchy, N. S., Chen, P., \& Jalaluddin, M. (2006). Functional Properties of Protein Isolate from Cowpea (Vigna unguiculata L. Walp.). Journal of Food Science, 69(2), 119-121.

Hron, R. J., Koltun, S. P., Pominski, J., \& Abraham, G. (1987). The potential commercial aspects of gossypol. Journal of the American Oil Chemists' Society, 64(9), 13151319.

Hron, R. J., Kuk, M. S., Abraham, G., \& Wan, P. J. (1994). Ethanol extraction of oil, gossypol and aflatoxin from cottonseed. Journal of the American Oil Chemists' Society, 71(4), 417-421.

Hur, S. J., Lim, B. O., Decker, E. A., \& McClements, D. J. (2011). In vitro human digestion 
models for food applications. Food Chemistry, 125(1), 1-12.

988 Jia, G., Zhan, Y., Wu, D., Meng, Y., \& Xu, L. (2009). An improved ultrasound-assisted extraction process of gossypol acetic acid from cottonseed soapstock. AIChE Journal, 55(3), 797-806.

991

992

993

994

995

996

997

998 Journal of the American Oil Chemists' Society, 60(2Part1), 229-242.

Khalaf, M. A., \& Meleigy, S. A. (2008). Reduction of free gossypol levels in cottonseed meal by microbial treatment. International Journal of Agriculture and Biology, 10(10), 185-90.

Kim, S.-Y., Je, J.-Y., \& Kim, S.-K. (2007). Purification and characterization of antioxidant peptide from hoki (Johnius belengerii) frame protein by gastrointestinal digestion. The Journal of Nutritional Biochemistry, 18(1), 31-38.

Kuk, M. S., \& Hron, R. J. (1994). Supercritical carbon dioxide extraction of cottonseed with co-solvents. Journal of the American Oil Chemists' Society, 71(12), 1353-1356.

Kuk, M. S., \& Hron, R. J. (1998). Cottonseed extraction with a new solvent system: Isohexane and alcohol mixtures. Journal of the American Oil Chemists' Society, 75(8), 927-930.

Kuk, M. S., \& Tetlow, R. (2005). Gossypol removal by adsorption from cottonseed miscella. Journal of the American Oil Chemists' Society, 82(12), 905-909.

Kumar, M. (2019b). Paruthi Paal, a nutrient-rich healthy drink from cottonseed: an Indian delicacy. Journal of Ethnic Foods, 6(1), 1-6.

Kumar, M., Dahuja, A., Sachdev, A., Kaur, C., Varghese, E., Saha, S., \& Sairam, K. V. S. S. (2019). Evaluation of enzyme and microwave-assisted conditions on extraction of anthocyanins and total phenolics from black soybean (Glycine max L.) seed coat. International journal of biological macromolecules, 135, 1070-1081. 
1012 Kumar, M., Mageshwaran, V., Saxena, S., D’Souza, C., Patil, S., Mahapatra A., ... \& Tak, Y.

1013

1014

1015

1016

1017

1018

1019

1020

1021

1022

1023

1024

1025

1026

1027

1028

1029

1030

1031

1032

1033

1034

1035

1036 (2019a). Value addition of cottonseed meal for feed industries by degossypolization employing papain and solvent. Research Journal of Biotechnology Vol, 14, 11.

Kumar, M., Potkule, J., Patil, S., Mageshwaran, V., Saxena, S.,...... \& D’Souza, C. (2021). Evaluation of detoxified cottonseed protein isolate for application as food supplement. Toxin reviews.

Kumar, M., Potkule, J., Patil, S., Saxena, S., Patil, P. G., Mageshwaran, V., ... \& D’Souza, C. (2021). Extraction of ultra-low gossypol protein from cottonseed: Characterization based on antioxidant activity, structural morphology and functional group analysis. $L W T, 110692$.

Kumar, M., Tomar, M., Potkule, J., Verma, R., Punia, S., Mahapatra, A., ... \& Kennedy, J. F. (2021). Advances in the Plant Protein Extraction: Mechanism and Recommendations. Food Hydrocolloids, 106595.

Lawhon, J. T. (1969). Processing methods to preserve quality and color of cottonseed flakes. Journal of the American Oil Chemists' Society, 46(7), 380-383.

Li, J., Pradyawong, S., He, Z., Sun, X. S., Wang, D., Cheng, H. N., \& Zhong, J. (2019). Assessment and application of phosphorus/calcium-cottonseed protein adhesive for plywood production. Journal of Cleaner Production, 229, 454-462.

Li, R., Hou, G. F., Song, Z. H., Zhao, J. F., Fan, Z. Y., Hou, D. X., \& He, X. (2019). Nutritional value of enzyme-treated soybean meal, concentrated degossypolized cottonseed protein, dried porcine solubles and fish meal for 10 - to $-20 \mathrm{~kg}$ pigs. Animal Feed Science and Technology, 252, 23-33.

Liadakis, G. N., Floridis, A., Tzia, C., \& Oreopoulou, V. (1993). Protein isolates with reduced gossypol content from screw-pressed cottonseed meal. Journal of Agricultural and Food Chemistry, 41(6), 918-922. 
1037 Liu, F.-K., Jou, S. Y., \& Jung, L. Y. (1981). A new method of detoxification of cottonseed by

1038

1039

1040

1041

1042

1043

1044

1045

1046

1047

1048

1049

1050

1051

1052

1053

1054

1055

1056

1057

1058 means of mixed solvent extraction. Journal of the American Oil Chemist's Society, 58(2), A93-A96.

Liu, M., Wang, Y., Wu, Y., He, Z., \& Wan, H. (2018). “Greener” adhesives composed of urea-formaldehyde resin and cottonseed meal for wood-based composites. Journal of Cleaner Production, 187, 361-371.

Lusas, E. W., Lawhon, J. T., Clark, S. P., Matlock, S. W., Meinke, W. W., Mulsow, D. W., Rhee, K. C., \& Wan, P. J. (1978). Potential for edible protein products from glandless Potential for edible protein products from glandless cottonseed. Proceedings, glandless cottonseed: its significance, status and prospects. USDA-ARS, Beltsville, MD, 31-43.

Lusas, E. W., Watkins, L. R., \& Koseoglu S. S., (1991). Isopropyl alcohol to be tested as solvent. INFORM, 2, 970-976.

Ma, M., Ren, Y., Xie, W., Zhou, D., Tang, S., Kuang, M., \& Du, S. (2018). Physicochemical and functional properties of protein isolate obtained from cottonseed meal. Food Chemistry, 240, 856-862.

Ma, X., Hu, J., Shang, Q., Liu, H., \& Piao, X. (2019). Chemical composition, energy content and amino acid digestibility in cottonseed meals fed to growing pigs. Journal of Applied Animal Research, 47(1), 280-288.

Mageshwaran, V., Sharma, V., Chinnkar, M., Parvez, N., \& Krishnan, V. (2018). Biodegradation of Gossypol by Mixed Fungal Cultures in Minimal Medium. Applied Biochemistry and Microbiology, 54(3), 301-308. 
1059 Moretti, D. B., Jimenez, C. R., Trinca, H. M., Machado-Neto, R., \& Louvandini, H. (2019).

1060

1061

1062

1063

1064

1065

1066

1067

1068

1069

1070

1071

1072

1073

1074

1075

1076

1077

1078

1079

1080

1081 Effect of maternal cottonseed feed on the immune and antioxidant status of Santa Ines lambs. Comparative Immunology, Microbiology and Infectious Diseases, 62, 58-63.

Murthy, M. V. R., Mohan E. V. S. \& Sadhukhan, A. K. (1999). Cyclosporin A production by Tolypocladium inflatum using solid state fermentation. Process Biochemistry, 34, 269-80

Nagalakshmi, D., Sastry, V. R. B., \& Agrawal, D. K. (2002). Detoxification of undecorticated cottonseed meal by various physical and chemical methods. Animal Nutrition and Feed Technology, 2(2), 117-126.

Nayefi, M., Salari, S., Sari, M., \& Behgar, M. (2014). Treatment by gamma or electron radiation decreases cell wall and gossypol content of cottonseed meal. Radiation Physics and Chemistry, 99, 23-25.

Ohno, A., Ano T., \& Shoda, M. (1992). Production of antifungal antibiotic, iturin in solid state fermentation by Bacillus subtilis NB 22 using wheat bran as substrate. Biotechnology Letters, 14, 817-822.

Pearce, K. N., \& Kinsella, J. E. (1978). Emulsifying properties of proteins: evaluation of a turbidimetric technique. Journal of Agricultural and Food Chemistry, 26(3), 716723.

Pelitire, S. M., Dowd, M. K., \& Cheng, H. N. (2014). Acidic solvent extraction of gossypol from cottonseed meal. Animal Feed Science and Technology, 195, 120-128.

Pons, W. A., Pominski, J., King, W. H., Harris, J. A., \& Hopper, T. H. (1959). Recovery of gossypol from cottonseed gums. Journal of the American Oil Chemists' Society, 36(8), 328-332. 
1082 Prat, D., Wells, A., Hayler, J., Sneddon, H., Mcelroy, C. R., Abou-shehada, S., \& Dunn, P. J.

1083

1084

1085

1086

1087

1088

1089

1090

1091

1092

1093

1094

1095

1096

1097

1098

1099

1100

1101

1102

1103

1104

1105

(2016). CHEM21 selection guide of classical- and less classical-solvents. Green Chemistry, 18, 288-296.

Rajarathnam, S., Shashirekha, M. N., \& Bano, Z. (2001). Biodegradation of gossypol by the white oyster mushroom, Pleurotus florida, during culturing on rice straw growth substrate, supplemented with cottonseed powder. World Journal of Microbiology and Biotechnology, 17(3), 221-227.

Rao, R. K., \& Arnold, L. K. (1958). Alcoholic extraction of vegetable oils. V. Pilot plant extraction of cottonseed by aqueous ethanol. Journal of the American Oil Chemists Society, 35(6), 277-281.

Rathore, K. S. Pandeya, D. Campbell, L. M., Wedegaertner, T. C., Puckhaber, L., Stipanovic, R. D., Thenell, J. S., Hague, S., \& Hake, K. (2020) Ultra-Low Gossypol Cottonseed: Selective Gene Silencing Opens Up a Vast Resource of Plant-Based Protein to Improve Human Nutrition. Critical Reviews in Plant Sciences, 39, 1, 1-29.

Rathore, K. S., Pandeya, D., Campbell, L. M., and Palle, S. R. 2019. Cotton transgenic event TAM66274. US patent Application 2019/0008113 A1.

Reyes-Jáquez, D., Casillas, F., Flores, N., Andrade-González, I., Solís-Soto, A., MedranoRoldán, H., ...\& Delgado, E. (2012). The Effect of Glandless Cottonseed Meal Content and Process Parameters on the Functional Properties of Snacks during Extrusion Cooking. Food and Nutrition Sciences, 03(12), 1716-1725.

Rhee, K. S., Ziprin, Y. A., \& Calhoun, M. C. (2001). Antioxidative effects of cottonseed meals as evaluated in cooked meat. Meat Science, 58(2), 117-123.

Saki, A. A., Pournia, K., Tabatabaie, M. M., Zamani, P., Haghighat, M., \& Salary, J. (2012). Effects of cottonseed meal supplemented with lysine and enzyme (Hydroenzyme XP) on 
egg quality and performance of laying hens. Revista Brasileira de Zootecnia, 41 (10), $2225-2231$.

1108 Saricaoglu F. T. (2019). Application of high-pressure homogenization (HPH) to modify functional, structural and rheological properties of lentil (Lens culinaris) proteins, International Journal of Biological Macromolecules, 144, 760-769

Saxena, D. K., Sharma, S. K., \& Sambi, S. S. (2012). Kinetics and thermodynamics of gossypol extraction from defatted cottonseed meal by ethanol, Polish Journal of Chemical Technology, 14, 29-34.

1114

Shawrang, P., Mansouri, M. H., Sadeghi, A. A., \& Ziaie, F. (2011). Evaluation and comparison of gamma- and electron beam irradiation effects on total and free gossypol of cottonseed meal. Radiation Physics and Chemistry, 80(6), 761-762.

Shi, A. H., Zhang, Y.,Qu, P., Yan, J. G., \& Xiao, H. J. (1998). Screening and breeding of highly-effected degrading cotton-phenol strains and study on detoxification technology and conditions. Acta Microbiologica Sinica, 38, 318-20.

Singh, A., \& Kaur, A. (2019). Comparative studies on seed protein characteristics in eight lines of two Gossypium species. Journal of Cotton Research, 2(1), 6, 1-12

Singh, S., Sharma, S. K., \& Kansal, S. K. (2019). Batch extraction of gossypol from cottonseed meal using mixed solvent system and its kinetic modeling. Chemical Engineering Communications, 206(12), 1608-1617.

Singh, S., Sharma, S. K., \& Kansal, S. K. (2020). Extraction of Natural Pigment Gossypol from Defatted Cottonseed Using 2-Propanol-Water Green Solvent, Its Kinetics and Thermodynamic Study. Arabian Journal for Science and Engineering, 5, 7539-7550.

Singh, S.,Sharma, S. K., \& Kansal, S. K., (2015). Extraction of Gossypol from Cottonseed. Review in Advance Science and Engineering, 4, 301-318. 
1130 Smith, A. K. (1971). Practical considerations in commercial utilization of oilseeds. Journal of American Oil and Chemist's Society, 48, 38-42.

1132 Song, W., Kong, X., Hua, Y., Li, X., Zhang, C., \& Chen, Y. (2020). Antioxidant and antibacterial activity and in vitro digestion stability of cottonseed protein hydrolysates. LWT, 108724.

Spadaro, J. J., \& Gardner, H. K. (1979). Food uses for cottonseed protein. Journal of the American Oil Chemists' Society, 56(3Part3), 422-424.

1137

Statista, (2020).

Accessed

on 25/07/2020. https://www.statista.com/statistics/259489/worldwide-production-of-cottonseed/

Sun, H., Jiang-Wu, T., Xiao-Hong, Y., Yi-Fei, W., Wang, X., \& Feng, J. (2012). Improvement of the nutritional quality of cottonseed meal by Bacillus subtilis and the addition of papain. International journal of Agriculture and Biology, 14(4).

Tabatabai, F., Golian, A., \& Salarmoeini, M. (2002). Determination and detoxification methods of cottonseed meal gossypol for broiler chicken rations. Agricultural Sciences and Technology, 16(1), 3-15.

Thurber, F. H., Vix, H. L. E., Pons, W.A. Jr., Crovetto, A. J., \& Knoepfler, N. B. (1954). The effect of processing conditions on the properties of screw-press cottonseed meal and oil. Journal of the American Oil Chemists' Society, 31(9), 384-388.

Tsaliki, E., Kechagia, U., \& Doxastakis, G. (2002). Evaluation of the foaming properties of cottonseed protein isolates. Food Hydrocolloids, 16(6), 645-652.

1150 Tsaliki, E., Pegiadou, S., \& Doxastakis, G. (2004). Evaluation of the emulsifying properties of cottonseed protein isolates. Food Hydrocolloids, 18(4), 631-637.

1152 United Nations Children's Fund (UNICEF), World Health Organization, International Bank for Reconstruction and Development/The World Bank. Levels and trends in child 
Estimates. Geneva: World Health Organization; 2020. Licence: CC BY-NC-SA 3.0 IGO.

1157 Vellaichamy, M. (2016). Optimization of Solid State Fermentation Process for Gossypol Detoxification in Heat Sterilized Cotton Seed Cake by Mixed Fungal Cultures. International Journal of Food and Fermentation Technology, 6(1), 97-102.

1160 Villalpando, A., Easson, M., Cheng, H. N., \& Condon, B. (2019). Use of cottonseed protein as a strength additive for nonwoven cotton. Textile Research Journal, 89(9), 17251733.

Wan, P. J., Pakarinen, D. R., Hron, R. J., Richard, O. L., \& Conkerton, E. J. (1995). Alternative hydrocarbon solvents for cottonseed extraction. Journal of the American Oil Chemists' Society, 72(6), 653-659.

1166 Wang, J., Clark, G., Ju, M., Castillo, S., \& Gatlin, D. M. (2020). Effects of replacing menhaden fishmeal with cottonseed flour on growth performance, feed utilization and body composition of juvenile red drum Sciaenops ocellatus. Aquaculture, 523, 735217.

Wang, Q. Y., Zhang, G., Zhao, J. B., Zhou, X. J., Dong, W. X., Liu, L., ... \& Zhang, S. (2019). Energy and nutrient digestibility of degossypolized cottonseed protein and its utilization as a protein source in nursery pigs. Livestock Science, 223, 53-59.

1173 Wedegaertner, T. \& Rathore, K. (2015). Elimination of gossypol in cottonseed will improve its utilization. Procedia Environmental Sciences, 29, 124-125.

1175 Weng, X. Y. \& Sun, J.Y. (2006). Kinetics of biodegradation of free gossypol by Candida tropicalis in solid-state fermentation. Biochemical Engineering Journal, 32, 226-32. meal. Scientia agricultura Sinica, 22, 82-6 
1179 Yang, X., Guo, J., \& Sun, J. (2011). Biodegradation of free-gossypol by a new fungus isolated

1180

1181

1182

1183

1184

1185

1186

1187

1188

1189

1190

1191

1192

1193

1194

1195

1196

1197

1198

1199

1200

1201

1202

1203 from cotton planted soil. African Journal of Microbiology Research, 5(19), 30663072.

Ye, G., Dong, X., Yang, Q., Chi, S., Liu, H., Zhang, H., Tan, B., \& Zhang, S. (2020). Lowgossypol cottonseed protein concentrate used as a replacement of fish meal for juvenile hybrid grouper (Epinephelus fuscoguttatus $q \times$ Epinephelus lanceolatus $\precsim$ ): Effects on growth performance, immune responses and intestinal microbiota. Aquaculture, 524, 735309.

Yin, B., Liu, H., Tan, B., Dong, X., Chi, S., Yang, Q., Zhang, S., \& Chen, L. (2018). Cottonseed protein concentrate (CPC) suppresses immune function in different intestinal segments of hybrid grouper + Epinephelus fuscoguttatus $\times{ }^{\lambda}$ Epinephelus $^{-1}$ lanceolatu via TLR-2/MyD88 signaling pathways. Fish \& Shellfish Immunology, 81, 318-328.

Zhang, J., Wedegaertner, T., Idowu, O. J., Flynn, R., Hughs, S. E., \& Jones, D. C. (2016). Registration of 'NuMex COT 15 GLS'glandless cotton. Journal of Plant Registrations, 10(3), 223-227.

Zhang, Q.-W., Lin, L.-G., \& Ye, W.-C. (2018b). Techniques for extraction and isolation of natural products: a comprehensive review. Chinese Medicine, 13(1).

Zhang, W. J., Xu, Z. R., Sun, J. Y., \& Yang, X. (2006a). Effect of selected fungi on the reduction of gossypol levels and nutritional value during solid substrate fermentation of cottonseed meal. Journal of Zhejiang University Science B, 7(9), 690-695.

Zhang, W. J., Xu, Z. R., Zhao, S. H., Sun, J. Y., \& Yang, X. (2007). Development of a microbial fermentation process for detoxification of gossypol in cottonseed meal. Animal Feed Science and Technology, 135(1-2), 176-186.

Zhang, W.-J., Xu, Z.-R., Zhao, S.-H., Jiang, J.-F., Wang, Y., \& Yan, X.-H. 
1204

1205

1206

1207

1208

1209

1210

1211

1212

1213

1214

1215

1216

1217

1218

1219

1220

1221

1222

1223

1224

1225

1226

1227

1228

(2006b). Optimization of process parameters for reduction of gossypol levels in cottonseed meal by Candida tropicalis ZD-3 during solid substrate fermentation. Toxicon, 48(2), 221-226.

Zhang, Y., Zhang, Z., Dai, L., Liu, Y., Cheng, M., \& Chen, L. (2018a). Isolation and characterization of a novel gossypol-degrading bacteria Bacillus subtilis strain Rumen Bacillus Subtilis. Asian-Australasian journal of animal sciences, 31(1), 63.

Zhou, J., Zhang, H., Gao, L., Wang, L., \& Qian, H.-F. (2015). Influence of pH and ionic strength on heat-induced formation and rheological properties of cottonseed protein gels. Food and Bioproducts Processing, 96, 27-34.

Zhuge, Q., Posner, E. S., \& Deyoe, C. W. (1988). Production study of a low-gossypol protein product from cottonseed meal. Journal of Agricultural and Food Chemistry, 36(1), $153-155$. 
1230 Figures:

1231 Fig. 1. The problem of malnutrition in South-East Asian countries in the age group of under 5

1232 years. (Black and Sesikiran, web source: https://www.nestle.com/sites/default/files/asset-

1233 library/documents/creating\%20shared\%20value/expert-opinions.pdf accessed on 25/12/2020).

1234

1235

1236

1237

1238

1239

1240

1241

1242

1243

1244

1245

1246

1247

1248

1249

1250

1251

1252

1253 
1255 Fig. 2. Flow chart describing the stages required for the use of cottonseed protein in food and

1256 feed. A) Deoiling of cottonseed to produce cottonseed meal (CSM) with 45-55\% protein.

1257 CSM at this stage can only be utilized as feed for large ruminant animals due to the presence 1258 of the toxic polyphenol gossypol. B) Degossypolization of CSM by physical, chemical, and 1259 biological methods resulted in its improved utilization as feed for both small ruminants and 1260 nonruminants. C) Extraction of protein from CSM resulted in wider applications, as gossypol 1261 levels further reduced gossypol in the obtained protein. D) Applications of cottonseed protein 1262 as a supplement in various food products.

1263

1264

1265

1266

1267

1268

1269

1270

1271

1272

1273

1274

1275

1276

1277

1278 
1279 Fig. 3. Schematic diagram showing the mechanism of physical, chemical and biological 1280 methods for degossypolization. A) Physical techniques - the application of gamma irradiation 1281 to cottonseed and cottonseed meal (CSM) resulted in a reduction in the overall gossypol 1282 content due to degradation or dimerization or an unknown mechanism. B) Chemical methods 1283 mainly use solvents that interact with the resin glands present in cottonseed or CSM, 1284 solubilizing gossypol. Intense scrubbing of solids occurs at the solid-liquid interface, causing 1285 efficient diffusion of the solute (gossypol) into the bulk liquid phase by molecular diffusion.

1286 C) The biological method of degossypolization mainly involves the use of solid-state 1287 fermentation by employing a microbial consortium. The exact mechanism of nullifying the 1288 effect of gossypol in CSM is unknown; however, laccase action is correlated with 1289 detoxification of the CSM by degrading or oxidizing the toxic aldehyde groups in the 1290 gossypol structure. 
1305 Fig. 4. Illustration showing the amino acid profile, functional properties, molecular size, food 1306 safety and regulatory issues, and application of cottonseed protein (CSP). A) The quality of

1307 the CSP is mostly determined by the amino acid composition. It can be seen from the figure 1308 that CSP has a nice balance of essential and nonessential amino acids. B) The functional 1309 properties of the CSP prompted its application in the preparation of baked dough, comminated 1310 meat, marshmallows, mousses, ice creams, bakery products, and sausage. C) Based on the 1311 nutritional and functional properties of cottonseed, various products have been developed, 1312 such as Paruthi Paal, Proflo, Incaparina, and Tamunuts, and used as functional ingredients in 1313 food products. D) In addition to a direct source of protein, CSP is also utilized as an indirect 1314 source of protein. The protein conversion ratio of eggs (2.6) is the most efficient in converting 1315 cottonseed protein into animal protein for human nutrition. E) Molecular weight studies of 1316 CSP showed that salt-soluble proteins are found in maximum concentrations, whereas 1317 alcohol-soluble proteins are minimal. F) The application of cottonseed flour or protein in food 1318 products should follow food safety and regulatory issues. The most critical parameters 1319 considered for application in foods are presented in the illustration. 
1332 Table 1. Use of solvent extraction and other methods for the extraction/removal of gossypol

\section{3 from cottonseed meal/flakes}

\begin{tabular}{|c|c|c|c|c|}
\hline $\begin{array}{l}\text { Cottonseed } \\
\text { material } \\
\text { used }\end{array}$ & Solvent utilized & $\begin{array}{l}\text { \% Gossypol removal (GR)/ \% } \\
\text { yield of gossypol }\end{array}$ & $\begin{array}{l}\text { Remaining gossypol } \\
\text { in seed/flakes/oil/ } \\
\text { Meal }(\%)\end{array}$ & Reference \\
\hline $\begin{array}{l}\text { Defatted } \\
\text { cottonseed } \\
\text { flakes }\end{array}$ & $90 \%$ aqueous butanone & $79.54 \%$ FG (flakes swell more) & $\begin{array}{l}0.225 \% \text { gossypol in } \\
\text { flakes }\end{array}$ & $\begin{array}{l}\text { (Dechary et } \\
\text { al., 1952) }\end{array}$ \\
\hline $\begin{array}{l}\text { Defatted } \\
\text { cottonseed }\end{array}$ & Solvent extraction with pure ethanol & $61.55 \%$ gossypol & $\begin{array}{l}\text { Less than } 0.04 \% \\
\text { gossypol }\end{array}$ & $\begin{array}{l}\text { (Saxena et al., } \\
\text { 2012) }\end{array}$ \\
\hline $\begin{array}{l}\text { Cottonseed } \\
\text { meal }\end{array}$ & $\begin{array}{l}\text { Acidic Ethanol; Ethanol-Water [95:5] with } \\
\text { 1.4 M phosphoric acid, } 2 \mathrm{hr} \\
\text { (solvent wash only) }\end{array}$ & $\begin{array}{l}\text { 94.53\% gossypol, Dry matter yield } \\
\text { high }\end{array}$ & $5.47 \%$ gossypol & $\begin{array}{l}\text { (Pelitire et al., } \\
\text { 2014) }\end{array}$ \\
\hline $\begin{array}{l}\text { Cottonseed } \\
\text { meal }\end{array}$ & $\begin{array}{l}\text { Acidic Ethanol; Ethanol-Water [95:5] with } \\
1.4 \mathrm{M} \text { oxalic acid, } 2 \mathrm{hr} \\
\text { (solvent and water wash) }\end{array}$ & $\begin{array}{l}93.07 \% \text { total gossypol, Dry matter } \\
\text { yield medium }\end{array}$ & $6.92 \% \mathrm{TG}$ & $\begin{array}{l}\text { (Pelitire et al., } \\
\text { 2014) }\end{array}$ \\
\hline $\begin{array}{l}\text { Cottonseed } \\
\text { meal }\end{array}$ & $\begin{array}{l}\text { Acidic Ethanol; Ethanol-Water [95:5] with } \\
1.0 \mathrm{M} \text { sulphuric acid, } 2 \mathrm{hr} \\
\text { (solvent and water wash) }\end{array}$ & $\begin{array}{l}95.7 \% \text { gossypol but dry matter } \\
\text { yields lowest }\end{array}$ & $4.3 \% \mathrm{TG}$ & $\begin{array}{l}\text { (Pelitire et al., } \\
\text { 2014) }\end{array}$ \\
\hline $\begin{array}{l}\text { Cottonseed } \\
\text { meal }\end{array}$ & Gamma and electron radiation & $\begin{array}{l}\text { Free gossypol reduction } 59.16 \% \text {, } \\
82.37 \% \\
\text { TG reduction- } 40 \%\end{array}$ & - & $\begin{array}{l}\text { (Nayefi et al., } \\
\text { 2014) }\end{array}$ \\
\hline Cottonseed & $\begin{array}{l}\text { Acidic solvent extraction using butanol- } \\
\text { ethanol-water }\end{array}$ & $94.73 \%$ total gossypol & $5.27 \% \mathrm{TG}$ & $\begin{array}{l}\text { (Singh et al., } \\
\text { 2019) }\end{array}$ \\
\hline $\begin{array}{l}\text { Cottonseed } \\
\text { flour }\end{array}$ & $\begin{array}{l}\mathrm{SC} \mathrm{CO}_{2} \text { with } 5 \% \text { co-solvent iso- propanol/ } \\
\text { Ethanol }\end{array}$ & - & $0.02 \%$ gossypol in oil & $\begin{array}{l}\text { (Kuk \& Hron, } \\
\text { 1994) }\end{array}$ \\
\hline Cottonseed & Liquid cyclone process & - & $\begin{array}{l}0.04-0.07 \% \text { FG \& } \\
0.30 \% \text { TG }\end{array}$ & (Smith, 1971) \\
\hline $\begin{array}{l}\text { Cottonseed } \\
\text { meal }\end{array}$ & Ethanol and hexane & TG reduced to 0.32 to $0.55 \%$ & $\begin{array}{l}\text { FG from } 0.013- \\
0.044 \%\end{array}$ & $\begin{array}{l}\text { (Liu et al., } \\
\text { 1981) }\end{array}$ \\
\hline $\begin{array}{l}\text { Cottonseed } \\
\text { meal }\end{array}$ & 95\% Ethanol & $\begin{array}{l}\text { More than } 50 \% \mathrm{TG} \text { and } 90 \% \\
\text { aflatoxin }\end{array}$ & - & $\begin{array}{l}\text { (Hron et al., } \\
\text { 1994]) }\end{array}$ \\
\hline $\begin{array}{l}\text { Cottonseed } \\
\text { flakes }\end{array}$ & Solvent extraction with heptane & - & $\begin{array}{l}0.23 \% \text { gossypol with } \\
\text { heptane }\end{array}$ & $\begin{array}{l}\text { [(Wan et al., } \\
1995)\end{array}$ \\
\hline $\begin{array}{l}\text { Cottonseed } \\
\text { flakes }\end{array}$ & Solvent extraction with isohexane & - & $\begin{array}{l}0.29 \% \text { gossypol with } \\
\text { isohexane }\end{array}$ & $\begin{array}{l}\text { (Wan et al., } \\
\text { 1995) }\end{array}$ \\
\hline $\begin{array}{l}\text { Hexane } \\
\text { miscella of } \\
\text { Cottonseed }\end{array}$ & $\begin{array}{l}\text { Solvent extraction miscella + adsorption } \\
\text { with Mag. Silicate }\end{array}$ & $96 \%$ gossypol & - & $\begin{array}{l}\text { (Kuk \& } \\
\text { Tetlow, 2005) }\end{array}$ \\
\hline $\begin{array}{l}\text { Cottonseed } \\
\text { meal }\end{array}$ & Iso-hexane $75 \%$ Ethanol $25 \%$ & $\begin{array}{l}89.3 \% \mathrm{FG} \\
42.8 \% \mathrm{TG}\end{array}$ & $\begin{array}{l}0.11 / 1.03 \mathrm{FG} \\
0.6 / 1.05 \mathrm{TG}\end{array}$ & $\begin{array}{l}\text { (Kuk \& Hron, } \\
1998)\end{array}$ \\
\hline $\begin{array}{l}\text { Cottonseed } \\
\text { flakes }\end{array}$ & $\begin{array}{l}\text { Solvent extraction with isohexane and } \\
\text { alcohol }\end{array}$ & $\begin{array}{l}70 \% \mathrm{FG} \\
\& 45 \% \mathrm{TG}\end{array}$ & $\begin{array}{l}0.41-0.72 \% \text { FG \& } \\
0.11-0.30 \% \text { TG }\end{array}$ & $\begin{array}{l}\text { (Kuk \& Hron, } \\
1998)\end{array}$ \\
\hline $\begin{array}{l}\text { Cottonseed } \\
\text { gums }\end{array}$ & $\begin{array}{l}\text { MEK with phosphoric acid and acid } \\
\text { hydrolysis }\end{array}$ & $\begin{array}{l}47 \% \text { gossypol recovery from gums; } \\
\text { Yield: } 41 \% \text { pure gossypol }(98 \%)\end{array}$ & & $\begin{array}{l}\text { (Pons et al., } \\
1959)\end{array}$ \\
\hline
\end{tabular}

1334 The table enumerates amounts of reduction in free (FG) and total gossypol (TG) from cottonseed materials using different solvents/methods 1335

1336

1337 
1339 Table 2. Brief overview of free gossypol detoxification by microbes using solid-state

1340 fermentation.

\begin{tabular}{|c|c|c|c|c|c|c|c|c|}
\hline \multirow{2}{*}{ Microorganism } & \multicolumn{5}{|c|}{ Optimum conditions } & \multirow{2}{*}{$\begin{array}{l}\text { Free gossypol } \\
\text { removed }(\%)\end{array}$} & \multirow{2}{*}{$\begin{array}{l}\text { Improveme } \\
\text { nt in protein } \\
\text { content }(\%)\end{array}$} & \multirow{2}{*}{ Reference } \\
\hline & $\begin{array}{l}\text { IMC } \\
(\%)\end{array}$ & pH & $\begin{array}{l}\text { Temp } \\
\left({ }^{\circ} \mathrm{C}\right)\end{array}$ & $\begin{array}{l}\text { Fermen- } \\
\text { tation } \\
\text { time (h) }\end{array}$ & $\begin{array}{l}\text { Inoculum level } \\
\text { (cells/g) }\end{array}$ & & & \\
\hline $\begin{array}{l}\text { Bacillus subtilis } \\
\text { GH38 }\end{array}$ & 50 & 6.5 & 39 & 72 & $10^{7}$ & 78.86 & 4.98 & $\begin{array}{l}\text { (Zhang et al., } \\
\text { 2018a) }\end{array}$ \\
\hline Candida tropicalis & 55 & 5.2 & 30 & 48 & $10^{7}$ & 88.6 & 15.24 & $\begin{array}{l}\text { (Khalaf et al., } \\
\text { 2008) }\end{array}$ \\
\hline C. tropicalis ZD-3 & 50 & & 30 & 48 & $\begin{array}{l}10 \mathrm{~g} \text { mycelia/Kg } \\
\text { substrate }\end{array}$ & 94.6 & 10.76 & $\begin{array}{l}\text { (Zhang et al., } \\
\text { 2007) }\end{array}$ \\
\hline $\begin{array}{l}\text { C. tropicalis ZAU- } \\
1\end{array}$ & 55 & 6.0 & 30 & 72 & $10^{7}$ & 92.29 & - & $\begin{array}{l}\text { (Weng \& Sun, } \\
2006 \text { ) }\end{array}$ \\
\hline $\begin{array}{l}\text { Saccharomyces } \\
\text { cerevisae ZD-5 }\end{array}$ & 50 & & 30 & 48 & $5 \mathrm{~mL}$ yeast inoculum & 88.51 & 11.09 & $\begin{array}{l}\text { (Zhang et al., } \\
\text { 2007) }\end{array}$ \\
\hline $\begin{array}{l}\text { Aspergillus niger } \\
Z D-8\end{array}$ & 50 & & 30 & 48 & $\begin{array}{l}10 \mathrm{~g} \text { mycelia/Kg } \\
\text { substrate }\end{array}$ & 85.15 & 22.23 & $\begin{array}{l}\text { (Zhang et al., } \\
\text { 2007) }\end{array}$ \\
\hline
\end{tabular}

1341 


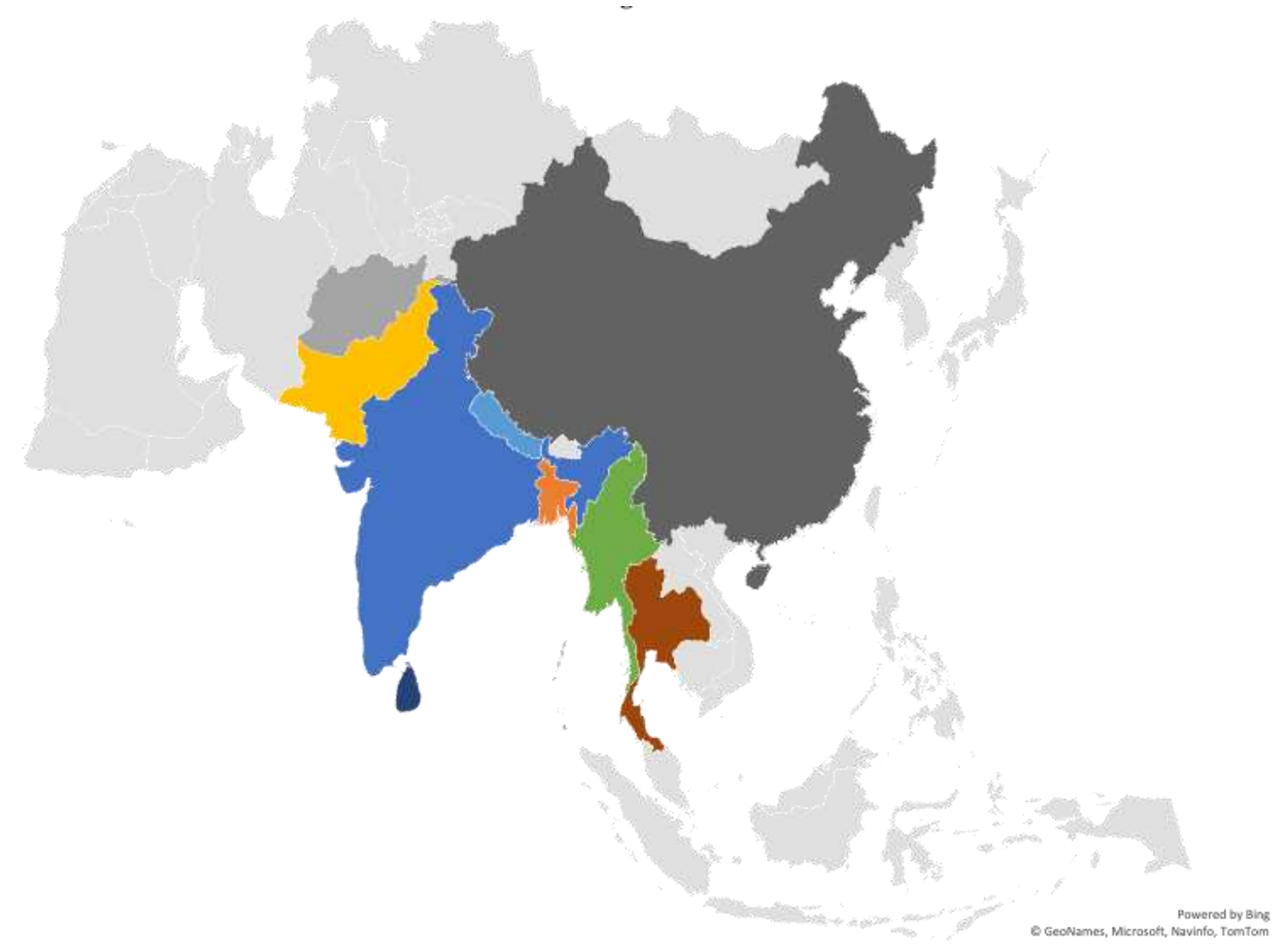

II India: $43 \%, 61$

I. Bangladesh: $41 \%, 46$

In Afganistan: 33\%, 101

Inakistan: $\mathbf{3 1} \%, \mathbf{7 2}$

Inepal: $\mathbf{2 9 \% , \mathbf { 4 8 }}$

II Myanmar: 23\%, 62

I Sri Lanka: $22 \%, 12$

W Thailand: $\mathbf{7 \% , 1 2}$

n China: $3 \%, 15$ 
Click here to access/download;Figure;Fig. 2.eps \pm
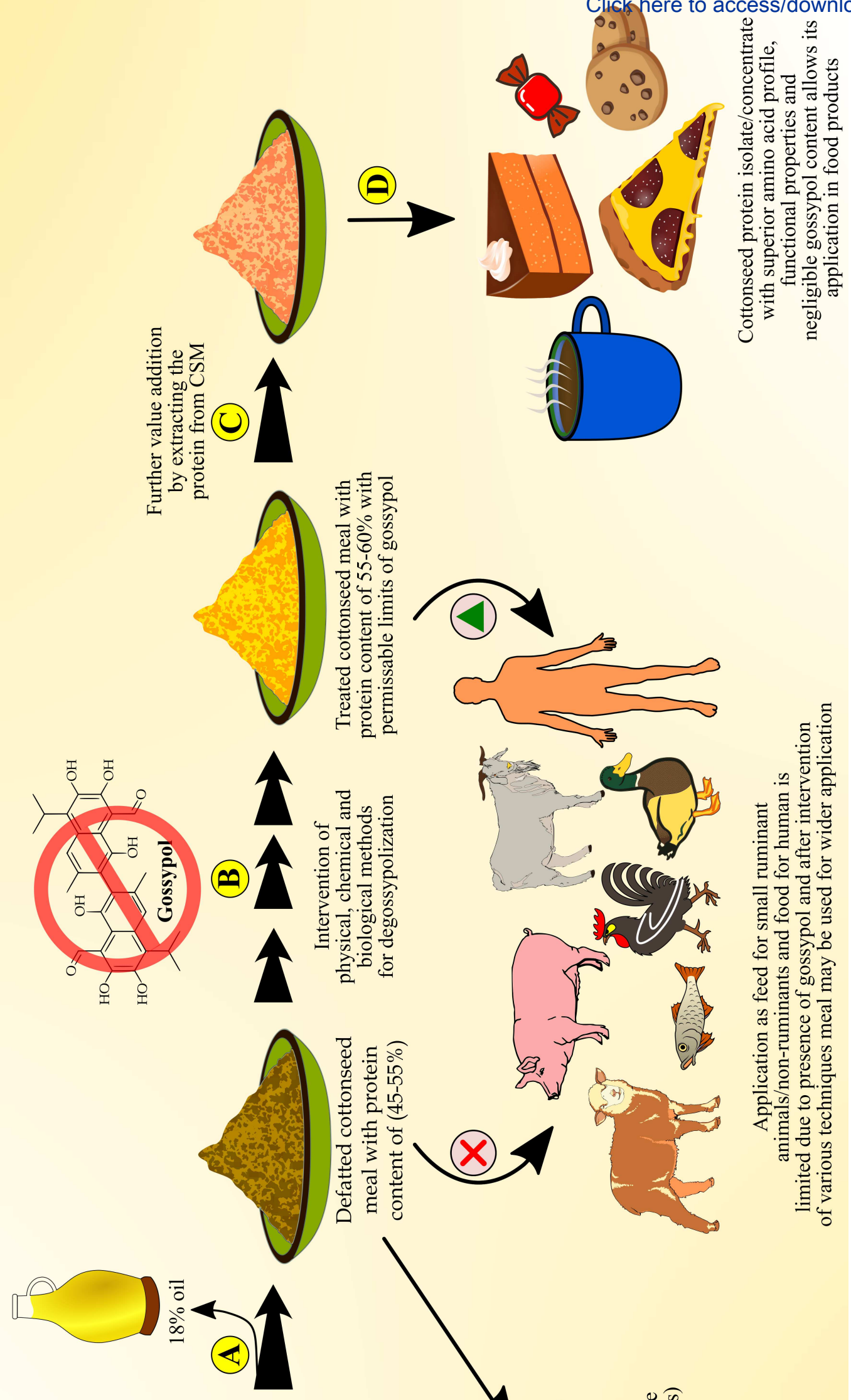

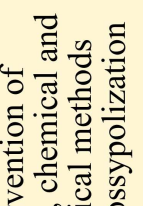

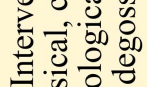

를
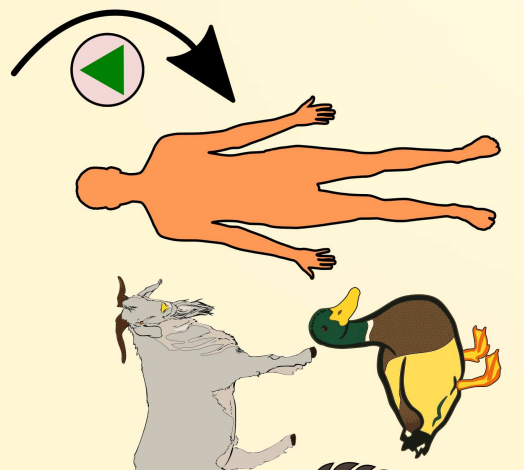

92

芶密.

छ屯े

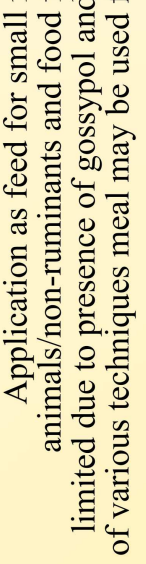

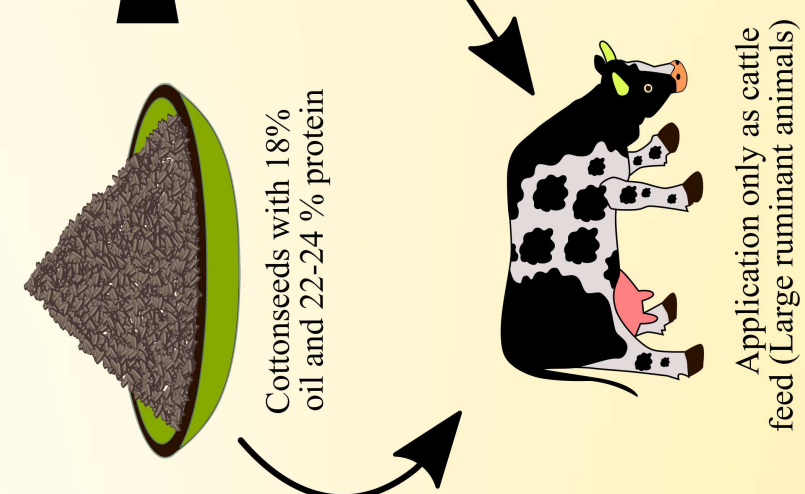



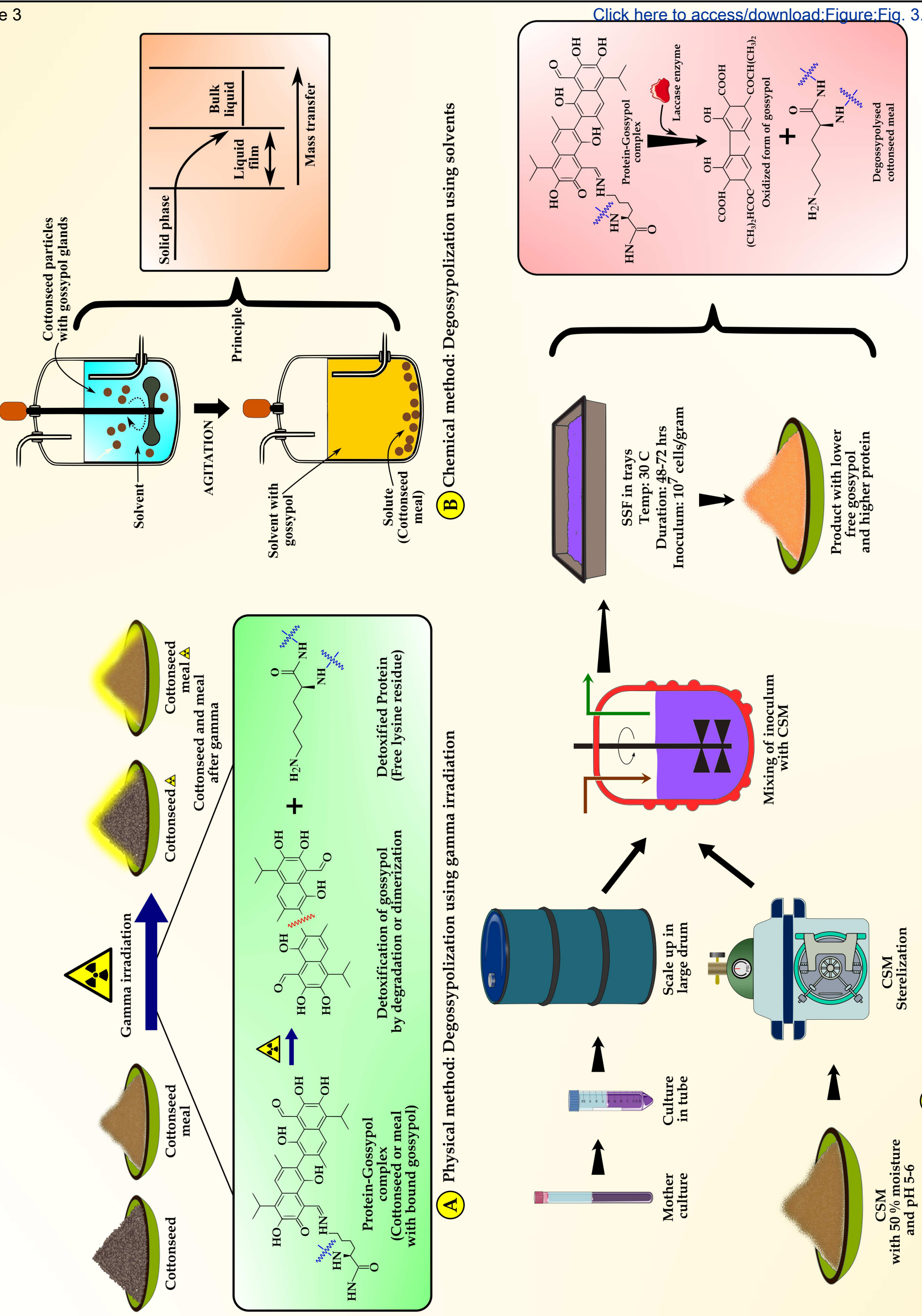


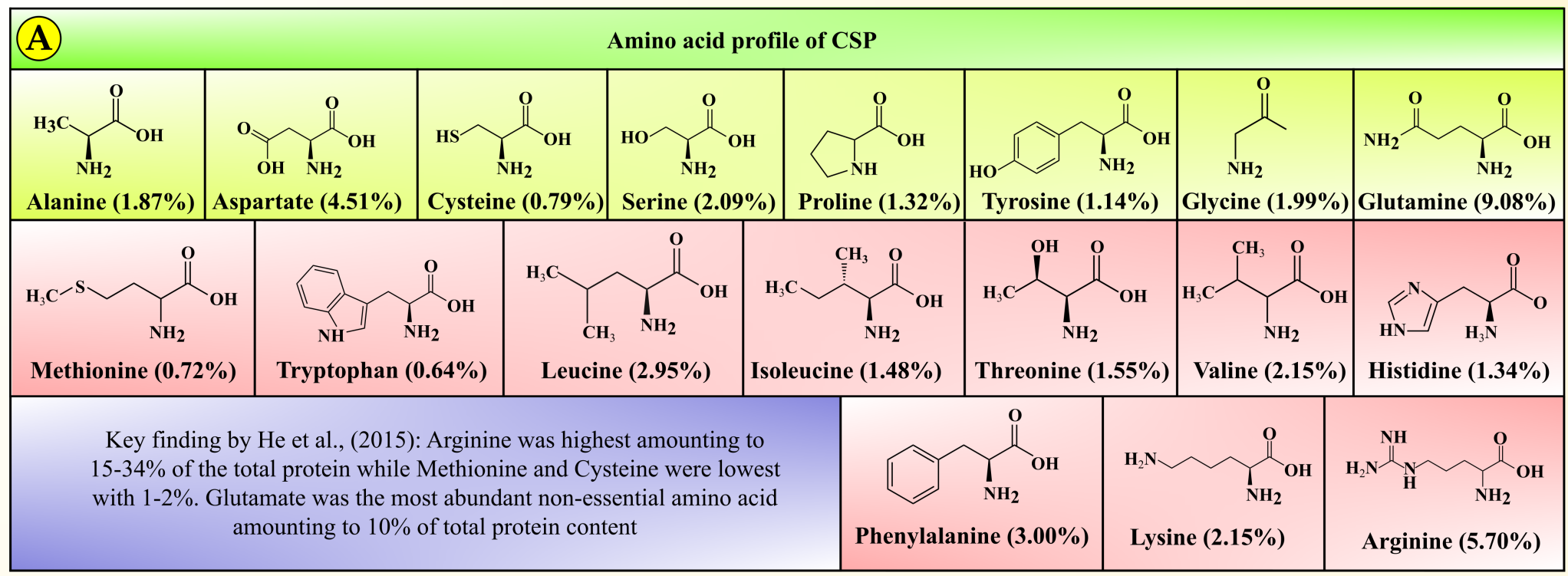

Functional properties of the CSP
(Ma et al., 2018, Tsaliki et al., 2002, 20

\begin{tabular}{|l|c|}
\hline Functional properties & Application \\
\hline WAC: $1.6-2.9 \mathrm{~g} / \mathrm{g}$ & \\
$\mathrm{OAC}: 3.0-5.4 \mathrm{~g} / \mathrm{g}$
\end{tabular}

PS: Highest at pH $11 \&$ Lowest at pH 5

\begin{tabular}{|c|c|}
\hline \multicolumn{2}{|c|}{ 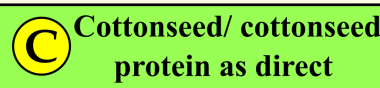 } \\
\hline & Paruthi Paal \\
\hline & Proflo \\
\hline & Incaparina \\
\hline & Tamunuts \\
\hline & $\begin{array}{l}\text { Food additive } \\
\text { nutritional } \\
\text { and functional } \\
\text { ingredient }\end{array}$ \\
\hline
\end{tabular}

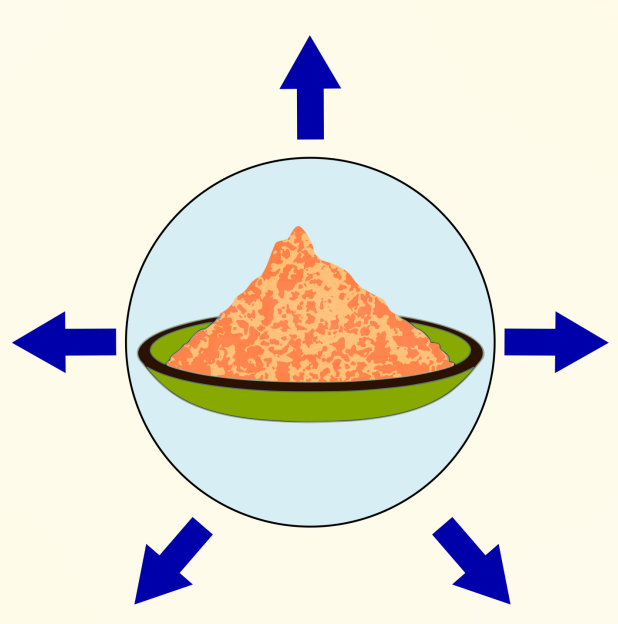

(F) Food safety and regulatory issues

These quality parameters include

Moisture content $<8 \%$

Crude protein $>47 \%$

Free gossypol content (FGC) $<0.06 \%$

Total gossypol content (TGC) $<1.2 \%$

Ash insoluble content $<0.35 \%$

Total ash content $<5.0 \%$

Available lysine $>3.6 \mathrm{~g} / 100 \mathrm{~g}$ of crude protein

Crude fibre content $<5.0 \%$

Fat content $<1.5 \%$ dry weight basis

Microbial count

Total bacterial count $<50000 / \mathrm{g}$

Coliform bacterial count $<10 / \mathrm{g}$

Salmonella bacterial count $<$ nil in $25 \mathrm{~g}$

Hexane $<10$ ppm

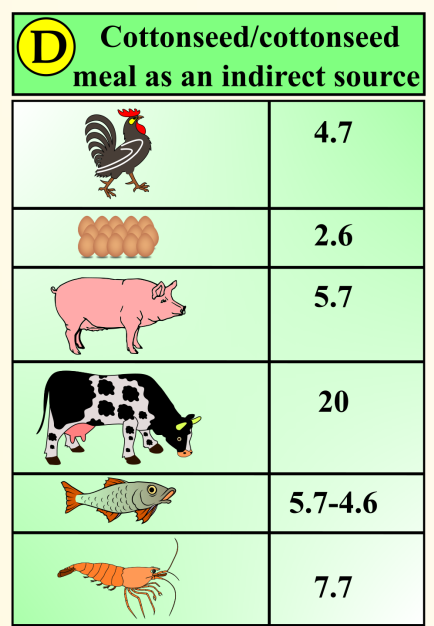

(E)

Molecular weight of CSP

- Non-reducing conditions: 50 and $45 \mathrm{kDa}$

- Reducing conditions: Additional bands between 35 and $14 \mathrm{kDa}$

- Type of protein: Protein contains salt soluble (globulins; 60-70\%), water soluble (albumins), alkali soluble (gliadins), and alcohol soluble fractions (prolamines) with balanced ratio of essential amino acids

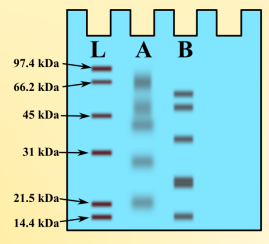

